\title{
Virkni endurskoðunarnefnda
}

\author{
Einar Guðbjartsson, Eypór Ívar Jónsson og Jón Snorri Snorrason ${ }^{1}$
}

\begin{abstract}
Ágrip
Tilgangur greinarinnar er að skoða virkni endurskoðunarnefnda út frá tíðni funda og gæði fundargagna. Könnun var gerð 2016 meðal nefndarmanna endurskoðunarnefnda hjá einingum tengdum almannahagsmunum. Könnunin veitir ákveðna innsýn í starfsumhverfi endurskoðunarnefnda og skoðanir nefndarmanna. Pessi rannsókn snýr að störfum endurskoðunarnefnda með tilliti til fjölda funda, fundargagna og umræðna. Störf og starfsumhverfi endurskoðunarnefnda hafa lítið verið rannsökuð og er greinin framlag í pá umræðu.

Verkefni endurskoðunarnefnda eru á ábyrgð stjórnar samkvæmt lögum um ársreikninga. Stjórnir purfa m.a. að sjá til pess að gögn og upplýsingar séu til staðar fyrir nefndarmenn og sett fram á réttan hátt. Nefndarmenn hafa einnig ábyrgð á pessum hluta í pví formi að kalla eftir nauðsynlegum gögnum hverju sinni, sérstaklega formaður. Umgjörð og fyrirkomulag endurskoðunarnefnda hefur mikið að segja um hvort tilgangur sem peim er ætlað næst eða ekki. Könnunin var gerð meðal fyrirtækja og stofnana sem falla undir skilgreininguna „einingar tengdar almannahagsmunum".

Til að meta gæði fundargagna voru settar fram prjár spurningar; hvort gögn komi með nægjanlegum fyrirvara, hvort gögn séu sett fram á fullnægjandi hátt og hvort gagnrýnar umræður fari fram á fundum. Nefndarmenn endurskoðunarnefnda mátu sjálfir pessa prjá pætti. Áhrifaríkasta tölugildi til að segja til um virkni endurskoðunarnefnda er fjöldi funda sem nefndin heldur. Fjöldi funda getur haft áhrif á hvort nefndin geti sinnt verkefni sínu. Pví verða notaðar breytur er tengjast fundum endurskoðunarnefnda, annars vegar fjöldi nefndarfunda og hins vegar fjöldi funda endurskoðunarnefnda með ytri endurskoðanda.

Til að kanna möguleg frávik í gæðum fundargagna eru breyturnar krosskeyrðar; fjöldi nefndarfunda, fjöldi funda með ytri endurskoðanda og allar prjár breyturnar er tilheyra gæðum fundargagna. Settar eru fram tvær tilgátur. Niðurstaðan er sú að vísbendingar eru um раð аð fjöldi nefndarfunda hafi tengsl við gæði fundargagna og umræðu en ekki fjöldi funda endurskoðunarnefnda með ytri endurskoðanda.

Einn megintilgangur endurskoðunarnefnda er að tryggja gæði og áreiðanleika fjárhagsskýrslna, gagnvart stjórn, hluthöfum og öðrum haghöfum. Verkefni og umfang endurskoðunarnefnda hafa aukist mjög síðustu árin. Endurskoðunarnefndir halda að meðaltali 5,2 fundi á ári. Hver fundur vegur pví um 20\% af hlutfallslegri heild. Virkni funda skiptir pví miklu máli. Góðir stjórnarhættir tengjast ekki eingöngu gæðum peirra gagna og upplýsinga sem félög og stofnanir senda frá sér, heldur einnig pví að innri stjórnskipan stuðli m.a. að væntingum samfélagsins hverju sinni og fylgni við lög.
\end{abstract}

1 Einar Guðbjartsson er dósent við viðskiptafræðideild Háskóla Íslands. Netfang: eg@hi.is. Eypór Ívar Jónsson er lektor við Copenhagen Business School. Netfang: ej.si@cbs.dk. Jón Snorri Snorrason er dósent við viðskiptadeild Háskólans á Bifröst. Netfang: jonsnorri@bifrost.is.

This work is licensed under a Creative Commons Attribution 4.0 License.

DOI: https://doi.org/10.24122/tve.a.2020.17.1.2 


\section{Abstract}

The purpose of this article is to examine effectiveness of audit committees with focus on the ratio and quality of meetings. A survey was conducted in 2016 among members of the Audit Committees at Public Interest Entities. The survey provides an overview regarding the working environment of the audit committees and the opinions of the committee members. This research deals with the process of audit committees with regarding to the number of meetings, meeting documents and discussions. There has been a lack of research regarding processes of the Audit Committees. The article is a contribution to that debate.

The tasks of the Audit Committees are the responsibility of the Board of Directors in accordance with the Annual Accounts Act. Boards require, inter alia, ensure that meeting documents and other information are available to committee members and presented correctly. Committee's members are also responsible for this section in the form of calling for the necessary documents at any time, especially the Chairman. The framework and arrangement of the Audit Committees are vital for its purpose. The survey was conducted among companies and institutions that fall within the definition of "public interest entities".

Assessing the quality of meeting documents was posed three questions; whether the meeting documents comes with sufficient notice, that it is adequately presented and that critical discussions take place at meetings. The members of the Audit Committees assessed the quality themselves. The most effective numerical value to indicate the effectiveness of the audit committees is the number of meetings the committee holds. Number of meetings can influence if the committee can carry out their tasks. Therefore, variables related to numbers of audit committee meetings will be used and number of committee meetings with an external auditor.

To investigate possible deviations in the quality of meeting documentation, the variables are cross-checked; the number of committee meetings, the number of meetings with the auditor and all three variables belong to the quality of the meeting documentation. Two hypotheses are presented. The findings, numbers of meetings have influence on the quality of the meetings documents regarding timing but not the number of meetings with external auditor.

One of the main purposes of the Audit Committees is to ensure the quality and reliability of financial reports. This applies to the board, shareholders, and other stakeholders. The activity of meetings is of great importance. The average meetings are 5.2 per year. Each meeting therefore weighs about $20 \%$ of the relative total. Good governance is not only related to the quality of the meeting documentation and information that companies and organizations transmit, but that internal governance promotes, among other things, to society's expectations and compliance with the law.

JEL flokkun: M140, M420, K220.

Lykilhugtök: Reikningsskil; endurskoðun; endurskoðunarnefndir; einingar tengdar almannahagsmunum.

Keywords: Accounting; auditing; audit committees; public interest entities.

\section{Audit Committees: Frequency of Meetings, Quality of Meet- ings Documents and Corporate Governance}




\section{Inngangur}

Á hinum vestræna hlutabréfa- og fjármagnsmarkaði hefur skilningur á mikilvægi endurskoðunarnefnda aukist mikið síðastliðna prjá áratugi. Fjármála- og reikningsskilahneyksli hafa eflaust átt stóran pátt í peirri próun. Gjaldprot sem urðu á árunum 1999 til 2001 og svo aftur 2008 til 2010 voru ákveðnir vendipunktar sem leiddu til aukins áhuga og áherslu á störf og starfsumhverfi endurskoðunarnefnda. Um áramótin 2000 var Blue Ribbon Committee skýrslan (BRC, 1999) birt og hafði hún mikil áhrif á innleiðingu endurskoðunarnefnda sem hluta af stjórnarháttum fyrirtækja. Skýrsluhöfundar beindu tilmælum sínum til stofnana á fjármálamarkaði en ekki til fyrirtækja á markaði varðandi framkvæmd við innleiðingu. Petta átti eftir að breyta leikreglum. Stofnanir á fjármálamarkaði voru til dæmis kauphallirnar í New York og Nasdaq. Pessar stofnanir tóku upp pær tillögur sem fram komu í BRC skýrslunni. Í framhaldinu hafði petta mikil áhrif á próun endurskoðunarnefnda um allan heim.

Árið 2009 var fest í lög viðbót við lög nr. 3/2006 um að skylda væri að skipa endurskoðunarnefndir og að nefndarmenn væru að lágmarki prír. Öll pau félög og stofnanir sem skilgreind eru sem einingar tengdar almannahagsmunum, sbr. lög nr. 94/2019, eru skyldug til að skipa endurskoðunarnefndir. Endurskoðunarnefnd er eina undirnefnd stjórnar sem er lögleidd. Í pessu felst m.a. mikilvægi hennar sem og vilji löggjafans að petta fyrirkomulag skuli gæta pess að ekki komi sambærilegar aðstæður upp og á árunum 2008 til 2010.

Endurskoðunarnefnd er undirnefnd stjórnar, skipuð af stjórn, og hefur bað hlutverk að hafa eftirlit með endurskoðun félagsins, p.m.t. reikningsskilum, ytri endurskoðun, innri endurskoðun og áhættustjórnun (McDaniel, Martin og Maines, 2002). Stjórn ber samt sem áður ábyrgð á pessum páttum. Í lögum um ársreikninga er að finna upptalningu á lágmarks verkefnum endurskoðunarnefnda. Starfsumfang og mikilvægi endurskoðunarnefnda hefur aukist mjög mikið síðustu árin (Appuhami og Tashakor, 2017; Kolk og Pinkse, 2010). Á sama tíma hefur flækjustig reikningsskila vaxið (Appuhami og Tashakor, 2017). Má hér nefna m.a. gangvirði (e. fair value) í reikningsskilum og er pað að verða veigameira en kostnaðarverðsreikningsskil. Í pessu samhengi má nefna eftirfarandi alpjóðlegu reikningsskilastaðlana IFRS 7, fjármálagerningar, skýringarpættir, IFRS 13, gangvirði og IFRS 16. leigusamningar. Fyrrnefndir staðlar krefjast ákveðinnar sérpekkingar og eru einnig skýringapungir. Tölulegar upplýsingar eru alltaf að minnka í hlutfalli við heildarumfang ársreikninga. Skýringar í ársreikningum eru að verða fyrirferðameiri en áður. Tvö stór verkefni varðandi efni í skýringarhluta ársreikninga (e. disclosure) hafa litið dagsins ljós síðustu árin: EFRAG, 2012, er stórt verkefni sem ætlað er að ná utan um hvað og hvernig eigi að skilgreina efni í skýringarhluta ársreikninga. Hitt er IFRS, 2017, par sem birt var umræðuskjal m.a. varðandi upplýsingar og framsetningu peirra. Í pessu sambandi má nefna IFRS 12, Skýringarpættir er tengjast tengdum einingum.

Endurskoðunarnefndir voru lögleiddar 1. janúar 2009 með frumvarpi um breytingu á ársreikningalögum, lög 3/2006. Breytingarnar má svo rekja til breytinga á tilskipun frá Evrópusambandinu, 2006/43 með síðari breytingum. Lágmarksfjöldi nefndarmanna eru prír og hefur verið óbreyttur frá 2009. Umfang og starfssvið endurskoðunarnefnda hefur breyst og aukist mjög mikið. Má nefna hér í pessu samhengi reglugerð nr. 537 frá 2014 útgefna af Evrópusambandinu. Par er að finna mörg ný starfsákvæði endurskoðunarnefnda, sjá kafla 11. Petta gerir pað að verkum að vinnuframlag nefndarmanna eykst að öðru óbreyttu. Til að halda vinnuálagi nefndarmanna óbreyttu parf að fjölga nefndarmönnum og/eða sjá til pess að endurskoðunarnefnd geti fengið utanaðkomandi pjónustu frá priðja aðila. Breytingar á endurskoðun hafa einnig verið umtalsverðar síðustu árin og má nefna endurskipulagningu endurskoðunar (e. Audit Reform) Evrópusambandsins frá 2014.

Tilgangurinn með pessum breytingum er að tryggja pað að glögg mynd (e. a true and fair view) endurspeglist í ársreikningum. Gerð og framsetning reikningsskila er orðinn lykilpáttur í góðum stjórnarháttum (DeZoort o.fl, 2002). Eitt af hlutverkum endurskoðunarnefnda er að hafa eftirlit með gerð og framsetningu reikningsskila (McDaniel o.fl., 
2002). Tilgangurinn endurspeglast í tilskipun Evrópuráđsins frá 2014 (EU, 2014) um starfsumfang endurskoðunarnefnda. Sjálfstæði endurskoðunarnefnda er lykilpáttur (Jenkins og Stanley, 2019; Church o.fl., 2018; DeZoort o.fl., 2002). Rannsóknir benda til pess að aukið sjálfstæði endurskoðunarnefnda hafi jákvæð áhrif á gæði reikningsskila (Mangena og Tauringana, 2008). Pó er álitamál hvort fyrirtæki sem hafa óháða nefndarmenn í endurskoðunarnefnd séu ólíklegri að kljást við vandamál eins og reikningsskilasvik. (McMullen og Raghunandan, 1996). Pess vegna leggja fræðimenn áherslu á að rannsaka hvort endurskoðunarnefndir séu skilvirkar og sýnilegar. Endurskoðunarnefnd hefur að einhverju leyti táknrænt hlutverk sem byggir á pví hvernig haghafa upplifa tilvist nefndarinnar (Brennan og Kirwan, 2015) sem og trúverðugleika hennar (Cohen o.fl., 2008, Spira, 2002).

DeZoort o.fl. (2002) gerðu samantekt á peim rannsóknum sem höfðu verið gerðar á peim tíma. Sú heimildavinna var síðar endurbætt og uppfærð (Bédard og Gendron, 2010). Samantekt á fræðigreinum um endurskoðunarnefndir sýnir að umboðskenningin (Fama og Jensen, 1983; Jensen og Meckling, 1976) hefur verið rauði práðurinn í rannsóknum síðustu tveggja áratuga. Útgangspunkturinn er að endurskoðunarnefndir hafa m.a. áhrif á gæði reikningsskila (Cohen, Krsihnamoorthy og Wrigth, 2004) og fjármagnskostnað (Anderson, Mansi og Reeb, 2004).

Eitt af peim atriðum sem lögleiðing endurskoðunarnefnda er ætlað að hafa áhrif á eru gæði endurskoðunar. Endurskoðun er mikilvæg fyrir hluthafa og aðra haghafa. Рað er viss tenging á milli gæða endurskoðunar og gæða fjárhagsupplýsinga (Li og Yang, 2015; Verriest o.fl., 2013). Við mat á gæðum endurskoðunar er m.a. horft til menningar endurskoðunarfélagsins, skilnings ytri endurskoðanda á starfsemi félagsins sem endurskoða skal, innri og ytri reynslu og fagpekkingu er tengist endurskoðun (ASIC). Par sem virkir fjármagnsmarkaðir er til staðar hefur verið lögð aukin áhersla á eftirlit og eftirfylgni gagngert til að auka áreiðanleika og gagnsæi fjármálaupplýsinga, m.a. vegna endurtekinna reikningsskila- og fjármálahneyksla. Til að ná pessu markmiði er skipun og uppbygging endurskoðunarnefnda hluti af góðum stjórnarháttum fyrirtækja (DeZoort o.fl., 2002). Skipan endurskoðunarnefnda leysir pó ekki allt (Bédard og Gendron, 2010).

Rannsóknir á endurskoðunarnefndum fjalla að mestu um umgjörð endurskoðunarnefnda en eiginleikar endurskoðunarnefnda hafa minna verið rannsakaðir og peir kraftar sem drífa nefndirnar áfram, p.e. nefndarmenn sjálfir, ferli og aðstæður (Wu o.fl., 2017). Hvatt hefur verið til aukinna rannsókna á störfum og ferlum endurskoðunarnefnda (DeZoort o.fl., 2002; Bédard og Gendron, 2010; Fiolleau o.fl., 2019). Rannsóknir á stjórnarháttum hafa í auknum mæli farið að snúast um skilvirkni stjórna með tilliti til hlutverks, verkefna, skipulags og starfshátta. Með svipuðum hætti hafa DeZoort o.fl. (2002) lagt áherslu á að mikilvægt sé að skilja hvernig endurskoðunarnefndir starfi til pess að geta metið betur markvirkni peirra.

Meginmarkmið rannsóknarinnar er að meta virkni endurskoðunarnefnda í íslenskum fyrirtækjum með pví að skoða fjölda funda, fundargögn og umræður á fundum. Grein pessi er sú priðja í röðinni um störf, umfang og starfsumhverfi endurskoðunarnefnda. Aðferðafræðin byggir á megindlegum grunni og könnun frá 2016.

\section{Rannsóknir á ferlum endurskoðunarnefnda}

Pekktasta líkanið sem fjallar um markvirkni endurskoðunarnefnda er líkan DeZoort o.fl. (2002). Líkanið er klassískt, inntak - ferli - útkoma, líkan par sem útkoman er markvirkni endurskoðunarnefnda. Inntakið eru hugtök eins og samsetning nefndar (e. composition), auðlindir og aðgengi (e. resources) og valdboð (e. authority). Flestar rannsóknir á endurskoðunarnefndum hafa fyrst og fremst snúist um að skoða inntak og útkomu en lítil sem engin áhersla hefur verið lögð á ferlið sjálft (Power og Gendron, 2015). Рað er hins vegar ferlið sjálft sem ákvarðar hvað nefndin gerir og hvort hún hafi í raun og veru áhrif (Brennan, 2015).

Brennan (2015) hefur fjallað um muninn á raunaðstæðum (e. practices) og pví sem í raun er gert (e. praxis). Með raunaðstæðum er átt við að skilningur sé sameiginlegur, s.s. 
lög, verkferlar o.fl., pví sem í raun gerist, p.e. peim ákvörðunum sem teknar eru. Petta eru tveir aðskildir ferlar. Hlutverk endurskoðunarnefndar er fyrst og fremst að hafa eftirlit með endurskoðunarferlinu og tengdum páttum og til pess аð pað ferli geti verið skilvirkt pá purfa ferlar nefndarinnar að vera virkir (Bédard og Gendron, 2010). Sjálfstæði nefndarinnar og pekking nefndarmanna er mikilvæg til pess að auka líkur á gæði reikningsskila (Jenkins og Stanley, 2019; Church o.fl., 2018; DeZoort o.fl, 2002; Mangena og Tauringana, 2008) en ef ferlar endurskoðunarnefnda eru ekki skilvirkir pá skila eiginleikar nefndarinnar sér ekki í jákvæðri útkomu (Bédard og Gendron, 2010). Allar ákvarðanir eru teknar á fundum nefndarinnar.

Rannsóknir á ferlum endurskoðunarnefnda einkennast af pví að finna breytur sem gefa vísbendingar um ferlið (DeZoort o.fl., 2002). Algengasti pátturinn sem skoðaður hefur verið er fjöldi funda endurskoðunarnefnda (Bédard og Gendron, 2010). Strax árið 2000 komu fram leiðbeiningar um fjölda funda (NACD, 2000). Par er lagt til að lágmarksfjöldi verði fjórir og að peir dreifist y fir alla ársfjórðunga. Ekki er pví talið æskilegt að allir fundir verði á tveggja mánaða tímabili. Í alpjóðlegum leiðbeiningum fyrir endurskoðunarnefndir er lagt til að nefndir purfi að hittast að lágmarki fjórum sinnum á ári til pess að ná markmiðum sínum og oftar ef um stærri fyrirtæki sé að ræða (Sabia og Goodfellow, 2005). Niðurstaða flestra rannsókna bendir til pess að meiri líkur séu á að endurskoðunarnefndir séu skilvirkari ef pær hittast oft en ef pær hittast sjaldan. Рað hefur áhrif á gæði reikningsskila og dregur úr líkum á sektum frá viðkomandi fjármálaeftirliti (McMullen og Raghunanden, 1996; Bedard o.fl., 2004; Braswell, 2018). Fjöldi funda eykur líkur á gagnsæi reikningsskila (Braswell, 2018).

Aðrir pættir sem hafa verið skoðaðir í samhengi við ferli endurskoðunarnefnda eru: Dagskrá funda, umræður og spurningar, samband og samskipti, völd og leiðtogapættir (Bédard og Gendron, 2010). Pá skiptir aðgengi að upplýsingum máli og samræður nefndarmanna í pessu samhengi pó að peir pættir séu stundum hluti af valdboði og inntaki endurskoðunarnefnda frekar en ferlinu sjálfu (Bédard og Gendron, 2010). Fræðimenn hafa leitað leiða til pess að leiða líkur að skilvirkni endurskoðunarnefnda með ólíkum hætti (DeZoort o.fl., 2002; Bédard og Gendron, 2010). Hér verður lögð áhersla á fjölda funda endurskoðunarnefnda, fjölda funda með ytri endurskoðendum, fullnægjandi fundargögn og gagnrýnar spurningar.

Umboðskenningin er sú kenning sem algengust er í rannsóknum á endurskoðunarnefndum og stjórnarháttum almennt (Bédard og Gendron, 2010). Мeð pví að hafa eftirlitshlutverk með reikningsskilum, innri endurskoðun og áhættustjórnun hefur nefndin pað hlutverk að tryggja hagsmuni eigenda félagsins eins og stjórn félagsins. Bæði stjórn og endurskoðunarnefnd vinna pannig í umboði eigenda við að tryggja að hagsmunir peirra séu hafðir í fyrirrúmi en ekki eiginhagsmunir stjórnenda félagsins (Fama og Jensen, 1983). Sjálfstæð og markvirk endurskoðunarnefnd getur pannig dregið úr freistnivanda stjórnenda. Tilvist, táknrænt gildi og trúverðugleiki endurskoðunarnefnda sem undirnefnd getur haft áhrif (Brennan og Kirwan, 2015; Cohen o.fl., 2008, Spira, 2002) en að lokum snýst árangur endurskoðunarnefndar sem mikilvægs páttar í eftirlitskerfinu um hvað hún í raun og veru gerir, p.e. hvort ferlarnir séu virkir (Brennan, 2015). Pá er spurningin líka út frá umboðskenningunni hvort endurskoðunarnefnd sinni pví starfi sem henni er ætlað á skilvirkan hátt.

Eitt mikilvægasta tækið í stjórnarháttum er að spyrja spurninga til pess að fá fram upplýsingarog mikilvægt er að nefndarmenn endurskoðunarnefnda búi yfir peirri kunnáttu (Sabia og Goodfellow, 2005). Í pessu samhengi má nefna hneykslismál eins og Enronmálið, par sem framsetning reikningsskila og endurskoðun var í molum og lykilaðilar eins og stjórn og nefndir stjórna hefðu átt að spyrja gagnrýnna spurninga (Bedard og Gendron, 2010). Að spyrja gagnrýnni spurninga eykur jafnframt sjálfstraust nefndarmanna og trúverðugleika peirra í pví samhengi sem nefndin starfar. Að spyrja spurninga er par af leiðandi lykilpáttur í ferli endurskoðunarnefnda og eykur jafnframt líkur á skilvirkni 
nefndarinnar (DeZoort o.fl., 2002). Pessi eiginleiki er bundinn einstaklingi sem nefndarmanni og pví er menntun og pekking mikilvægur hlekkur í samhenginu. Par sem vinna hefur verið lögð í að auka gæði fundargagna eykur pað líkurnar á að nefndarmenn geti spurt réttu spurninganna á gagnrýnan hátt og samræður geti leitt til aukinna gæða reikningsskila og endurskoðunar.

\subsection{Fundargögn og fjöldi funda}

Nefndarfundir og fundir með ytri endurskoðanda eru haldnir til pess að uppfylla fylgni samkvæmt lögum. Fjöldi nefndarfunda hefur verið álitinn einn páttur í pví að endurskoðunarnefndir séu skilvirkar. Líkur eru leiddar að pví í BRC (1999) að góðir stjórnarhættir leiði til fleiri funda endurskoðunarnefnda. Félög sem hafa verið uppvís að reikningsskilasvikum eða fjármálamisferli hafa haft færri nefndarfundi en önnur félög sem ekki hafa orðið uppvís að reikningsskilasvikum eða fjármálamisferli (Beasley o.fl., 2000; McMullen og Raghunanden, 1996; Bedard o.fl., 2004; Braswell, 2018).

Fjöldi funda er einn af peim páttum sem hefur áhrif á umhverfi og einnig hversu mikil áhrif endurskoðunarnefnd hefur. Ákveðinn sýnileiki sem fæst með fjölda funda er mikilvægur fyrir nefndarmenn endurskoðunarnefnda og ekki síður starfsmenn t.d. á reikningshaldssviði eða á fjármálasviði (Deloitte). Erindisbréf stjórnar til nefndarmanna endurskoðunarnefnda hvað varðar viðfangsefni, verkefni og umfang er mjög mikilvægt. Erindisbréf á að vera formlegt. Kauphallir í Bandaríkjunum og Bretlandi hafa gert pá kröfu að slík erindisbréf séu gerð og pau endurskoðuð á a.m.k. priggja ára fresti. Hér markar stjórn sýnileika endurskoðunarnefndar með pví t.d. að ákvarða ábyrgð, skyldur, mannaforráð, starfsumhverfi nefndarmanna og jafnvel ákveða lágmarksfjölda nefndarfunda. Til að auka sýnileika getur formaður endurskoðunarnefndar mætt á aðalfund félagsins og sagt frá skyldum og störfum nefndarinnar (FEE, 2006).

Eitt af lykilatriðum sem gerir pað аð verkum að fundur skilar árangri er frágangur fundargagna. Umfang málefna sem endurskoðunarnefnd parf að hafa umsjón með og sinna hefur aukist mikið síðustu árin. Skortur er á rannsóknum sem tengjast fundargögnum sem nefndarmenn fá til að sinna skyldum sínum (DeZoort o.fl., 2002; Brédard og Gendron, 2010). Möguleiki nefndarmanna til að uppfylla eftirlitshlutverk hvílir að stórum hluta á peim gæðum fundargagna sem nefndarmenn fá. Fundargögn eiga að vera af miklum gæðum, heildstæð, nákvæm og berast tímanlega (Brédard og Gendron, 2010).

Gæði fundargagna geta haft mótandi áhrif á pað hvort endurskoðunarnefnd hefur áhrif innan síns starfsumhverfis. Eitt af pví sem getur tryggt gæði fundargagna er að nefndarmenn fái fundargögn með nægjanlegum fyrirvara. Með nægjanlegum fyrirvara er átt við að nefndarmenn geti lesið og gert sér grein fyrir peim málum sem leysa parf úr eða taka afstöðu til á næsta nefndarfundi. Frumlestur gagna á fundi getur orðið til pess að niðurstaða fundar verði óskilvirk. Nægjanlegur fyrirvari á fundargögnum er einn páttur í pví að gæta pess að fullnægjandi fundargögn berast nefndarmönnum.

Pekking og reynsla nefndarmanna á mikinn pátt í pví að nefndarmaður geti metið hvað séu fullnægjandi fundargögn (Brennan, 2015). Pess vegna eru samskipti nefndarmanna mikilvæg t.d. varðandi fundargögn. Oft er pað formaður endurskoðunarnefndar sem útbýr fundarboð og fundargögn. Á nefndarfundi eru gagnrýnar umræður mikilvægur páttur í pví að stuðla að virkni endurskoðunarnefnda og ekki síður í peim tilgangi að auka gæði endurskoðunar. Pessi gagnrýni er jafnmikilvæg og fagleg efasemdanálgun (e. scepticism) og fagleg dómgreind (e. judgement) (CPA, 2017) .

Gæði fundargagna verða að vera á pví stigi að nefndarmenn geti sett sig inn í efni fundar og tekið upplýsta ákvörðun byggða á gögnum (Jean og Gendron, 2010). En áður en ákvörðun er tekin verða að hafa átt sér stað virkar umræður. Sérstaklega par sem gagnrýnar spurningar hafa komið fram. Hér má nefna atriði eins og flókin reikningsskilaleg atriði, óhæði endurskoðanda, fylgni við lög o.fl.

Rannsóknir benda til pess að fjöldi funda endurskoðunarnefnda hafi áhrif á útkomu 
starfsins og leiði t.d. til minni sviksemi og aukinna gæða reikningsskila (McMullen og Raghunanden, 1996; Bedard o.fl., 2004; Braswell, 2018). Рað gefur tilefni til pess að meta hvort fjöldi funda hafi jafnframt tengsl og par með mögulega áhrif á skilvirkni nefndarstarfsins, annars vegar út frá fundargögnum (Jean og Gendron, 2010) og hins vegar út frá umræðum nefndarmanna (Sabia og Goodfellow, 2005). Tvær tilgátur eru settar fram, annar vegar út frá fjölda funda endurskoðunarnefnda og hins vegar út frá fjölda funda endurskoðunarnefnda með endurskoðendum.

Tilgáta 1:- Gæði fundargagna endurskoðunarnefnda eru ekki tengd við fjölda nefndarfunda.

Tilgáta 2: Gæð̇ fundargagna endurskoðunarnefnda eru ekki tengd við fjölda nefndarfunda með ytri endurskoðendum.

Tilgangur með tilgátunum er að kanna hvort fjöldi funda hafi tengsl við gæði fundargagna að mati nefndarmanna og hafi pannig óbein áhrif á markvirkni endurskoðunarnefnda. Fundargögn endurspegla viðfangsefni og umræður á nefndarfundum. Pessi aðföng sem nefndarmenn fá eru að öllum líkindum unnin af formanni endurskoðunarnefndarinnar. Formenn bera hér mikla ábyrgð og hafa mikil áhrif á gang mála og hvernig starfsumhverfi nefndanna próast. Einnig verður skoðað hvort fjöldi funda hafi tengsl og par með möguleg áhrif á pað hvort virkar umræður séu pegar gagnrýnar spurningar eru bornar upp.

Einn páttur sem hefur einnig áhrif er erindisbréf stjórnar til endurskoðunarnefndar (DeZoort o.fl., 2002). Par kemur fram vilji stjórnar og einlægni í garð nefndarinnar. Endurskoðunarnefnd er undirnefnd stjórnar en hefur pá sérstöðu að vera skipuð samkvæmt lögum. Stjórn hefur ekkert val um pað hvort nefndin verði skipuð eða ekki, heldur hverjir verði skipaðir.

\section{Aðferðafræði og pátttaka}

Meginmarkmið rannsóknarinnar er að meta virkni endurskoðunarnefnda í íslenskum fyrirtækjum með pví að skoða fjölda funda, fundargögn og umræður á fundum. Engar rannsóknir hafa verið gerðar á endurskoðunarnefndum á Íslandi sem miða að pví að skoða pessa pætti. Árið 2016 gerðu höfundar stóra könnun á starfsemi endurskoðunarnefnda á Íslandi. Pessi rannsókn nýtir hluta af peim spurningum sem par voru settar fram. Hér fyrir neðan er farið yfir spurningakönnunina í heild sinni og svo pær spurningar sem pessi rannsókn byggir á.

Rannsóknin er megindleg og byggir á upplýsingaöflun í formi spurningakönnunar. Hún er gerð með nákvæmum og kerfisbundnum hætti og niðurstöður eru settar fram á tölfræðilegan hátt til að styðja eða fella tilgáturnar (Ragnheiður Harpa Arnardóttir, 2013). Kostir spurningakannana eru að pær eru ódýr, einföld og pægileg leið til gagnaöflunar; hvorki parf að ná til fólks á tilteknum tíma né hætta á að skekkjur verði vegna áhrifa spyrla auk pess sem svarendur hafa betra næði til að svara (Churchill, 2002).

Spurningakönnunin innihélt 41 spurningu, par af 37 viðhorfs- og mælispurningar og fjórar bakgrunnsspurningar. Spurningar voru flokkaðar í átta flokka: Bakgrunnsupplýsingar, tenging við endurskoðunarnefnd, starfsumhverfi endurskoðunarnefndar, umfang endurskoðunarnefndar, umfang í tíma og samsetning, áframhaldandi nefndarseta, upplýsingar um innra og ytra umhverfi, endurskoðunarnefnd og ytri endurskoðun. Allar spurningar voru lokaðar (e. closed-ended) og fjöldi svarmöguleika í hverri spurningu var frá einum upp í 6. Notast var við lausnir frá Questionpro.com við framkvæmd könnunarinnar og við úrvinnslu á niðurstöðum. (Einar Guðbjartsson og Jón Snorri Snorrason, 2017).

\subsection{Framkvæmd og pátttaka}

Við gerð könnunar parf að ákveða stærð úrtaksins, hvort pað á að endurspegla allt pýðið 
eða ekki. Í könnuninni frá 2016 voru spurningar lagðar fyrir allt pýðið og svarhlutfallið notað til að álykta um heildina.

Á árinu 2016 var könnun framkvæmd á starfsumhverfi endurskoðunarnefnda. Sendur var út spurningalisti til stærstu fyrirtækja og stofnana landsins sem falla undir skilgreininguna „einingar tengdar almannahagsmunum". Við framkvæmd könnunar var spurningalisti sendur á tölvupóstföng nefndarmanna í endurskoðunarnefndum. Í spurningalistanum var m.a. óskað eftir upplýsingum um samsetningu og umfang endurskoðunarnefnda í pví augnamiði að varpa ljósi á aðstæður og umfang. Jafnframt var óskað eftir upplýsingum um bakgrunn nefndarmanna, pekkingu, reynslu og viðhorf peirra til áhrifa og ábyrgðar.

Framkvæmdaraðferð var valin með pað að markmiði að ná til sem flestra nefndarmanna í endurskoðunarnefndum við pau fyrirtæki, stofnanir og sveitarfélög sem falla undir lagalegu skilgreininguna ,eining tengd almannahagsmunum“, sbr. lög um endurskoðendur og endurskoðun. Heildarfjöldi eininga var 133. Einingarnar hafa mismunandi rekstrarform, t.d. hlutafélög, sveitarfélög, stofnanir og lífeyrissjóðir. Engin skráning er til um nefndarmenn endurskoðunarnefnda líkt og stjórnarmenn félaga, stofnana og sjóða og er pví gagnsæi gagnvart endurskoðunarnefndum í algjöru lágmarki. Slæmt aðgengi og upplýsingar um endurskoðunarnefndir er í raun pversögn við ætlaðan tilgang tilskipunar Evrópupingsins og Evrópuráðsins (EU, 2006).

Einingunum var svo skipt í fimm flokka: Fyrirtæki, stofnanir, lífeyrissjóðir, sveitarfélög og annað. Af heildarpýði, 133, svöruðu 77 einingar og 47 af peim voru með endurskoðunarnefnd, 30 einingar svöruðu pví til að engin nefnd væri starfandi. Ekkert svar barst frá 56 einingum. Pýðið endaði í að vera 126 einstök tölvupóstföng hjá nefndarmönnum endurskoðunarnefnda. Alls bárust svör frá 69 pátttakendum sem gerir um 55\% svarhlutfall. Ekki fengust svör frá öllum einingum í pýðinu og pví er ekki hægt að fullyrða um endanlegan fjölda endurskoðunarnefnda. Kynjahlutfall pátttakenda er mjög svipað pví hlutfalli sem er í heildarpýðinu (Einar Guðbjartsson og Jón Snorri Snorrason, 2017).

\subsection{Spurningar og úrvinnsla}

Meginmarkmið rannsóknarinnar er að meta virkni endurskoðunarnefnda í íslenskum fyrirtækjum með pví að skoða fjölda funda, fundargögn og umræður á fundum. Petta getur gefið vísbendingu um virkni endurskoðunarnefnda. Greinin fjallar pví um afmarkaða pætti könnunar sem gerð var 2016. Engar rannsóknir hafa verið gerðar á endurskoðunarnefndum á Íslandi sem miða að pví að skoða pá pætti sem fram koma í tilgátunum tveimur. Раð eru nefndarmenn sem leggja mat á viðkomandi fundargögn.

Rannsóknir hafa verið gerðar á endurskoðunarnefndum, par sem kannaðir eru pættir eins og samsetning nefndanna og fjölbreytni peirra, í peim tilgangi að meta hversu líklegir pessir pættir væru til að hafa áhrif á markvirkni endurskoðunarnefnda. Markmið með rannsóknunum er m.a. að gefa innsýn í starfsemi endurskoðunarnefnda út frá sjónarmiði nefndarmanna (Einar Guðbjartsson o.fl., 2018).

Rannsóknin hér er unnin út frá fimm spurningum sem eru hluti af könnuninni frá 2016. Með vali á spurningum er efnisval greinarinnar afmarkað. Pessar spurningar eru:

Nr. 1 Hver var fjöldi nefndarfunda á síðastliðnu rekstrarári (kjörtímabili endurskoðunarnefndar)?

Nr. 2 Hversu oft fundaði endurskoðunarnefnd með ytri endurskoðanda á síðastliðnu rekstrarári/kjörtímabili?

Nr. 3 Færð pú fundargögn með nægjanlegum fyrirvara til pess að geta sett pig inn í málefni næsta fundar?

Nr. 4 Telur pú að pau fundargögn sem pú færð fyrir hvern fund séu fullnægjandi svo pú getir sinnt hlutverki pínu sem nefndarmaður?

Nr. 5 Eru virkar umræður á fundum par sem bornar eru upp gagnrýnar spurningar? 
Spurning nr. 1 tilheyrir tilgátu 1 og spurning nr. 2 tilheyrir tilgátu nr. 2. Spurningar nr. 3, 4 og 5 eru krosskeyrðar við spurningarnar sem tilheyra tilgátum, hver fyrir sig. Niðurstöðum er lýst í súluritum fyrir krosskeyrslu og svo í töflum eftir krosskeyrslu. Upplýsingar um petta efni hafa ekki birst áđur hér á landi.

Kí kvaðratpróf er að lokum notað til pess að mæla hvort niðurstöður eru tölfræðilega marktækar og pví möguleg tengsl á milli breytanna. Par sem sum gildin eru færri en fimm pá er einnig reiknað „Fisher's exact test“ til að athuga hvort niðurstaðan úr peim útreikningi verði önnur en kí kvaðrat niðurstaðan. Fjöldi nefndarfunda endurskoðunarnefnda er flokkaður í tvo hópa; 1) fjöldi funda prír eða færri og 2) fjöldi funda fjórir eða fleiri. Fjöldi funda með ytri endurskoðanda er flokkaður í tvo hópa; 1) fjöldi funda með ytri endurskoðanda tveir eða færri og 2) fjöldi funda með ytri endurskoðanda prír eða fleiri.

Tilgangurinn er að skoða mögulegt tengsl á milli fjölda funda og fundargagna. Fjöldi funda getur mögulega gefið vísbendingu um lágmarksfjölda funda svo komast megi hjá pví að gæði fundargagna séu lítil. Með pessu er mögulega hægt að fá fram vísbendingar sem hafa áhrif á verkferla og virkni endurskoðunarnefnda.

\section{Niðurstöður}

Niðurstöður eru flokkaðar eftir spurningum. Í fyrri hluti kaflans, 4.1 til 4.5, eru lýsandi niðurstöður úr peim fimm spurningum sem notaðar eru í rannsókninni. Framsetning er í formi súlurits. I seinni hluta kaflans, 4.6 og 4.7, er farið y fir niðurstöður úr krosskeyrslum á spurningum nr. 3, 4 og 5 með tilliti til spurninga nr. 1 og 2.. Par er einnig gerð grein fyrir niðurstöðum úr kí kvaðratprófi. Í lok kaflans 4.8, er samantekt á niðurstöðum.

\subsection{Fjöldi nefndarfunda}

Fjöldi nefndarfunda fer eftir aðstæðum en pað er formaður sem boðar fundi. Ekki er æskilegt að hafa færri en prjá fundi fyrir hvert rekstrarár sem og endurskoðunartímabilið (FRC, 2012). Pannig er pað á ábyrgð formanns að boða til funda og að fjöldi funda sé í samhengi við aðstæður innan fyrirtækis sem utan. Áður hefur komið fram að NACD ráðleggur að lágmarki fjóra fundi á ári og að peim sé dreift á ársfjórðunga.

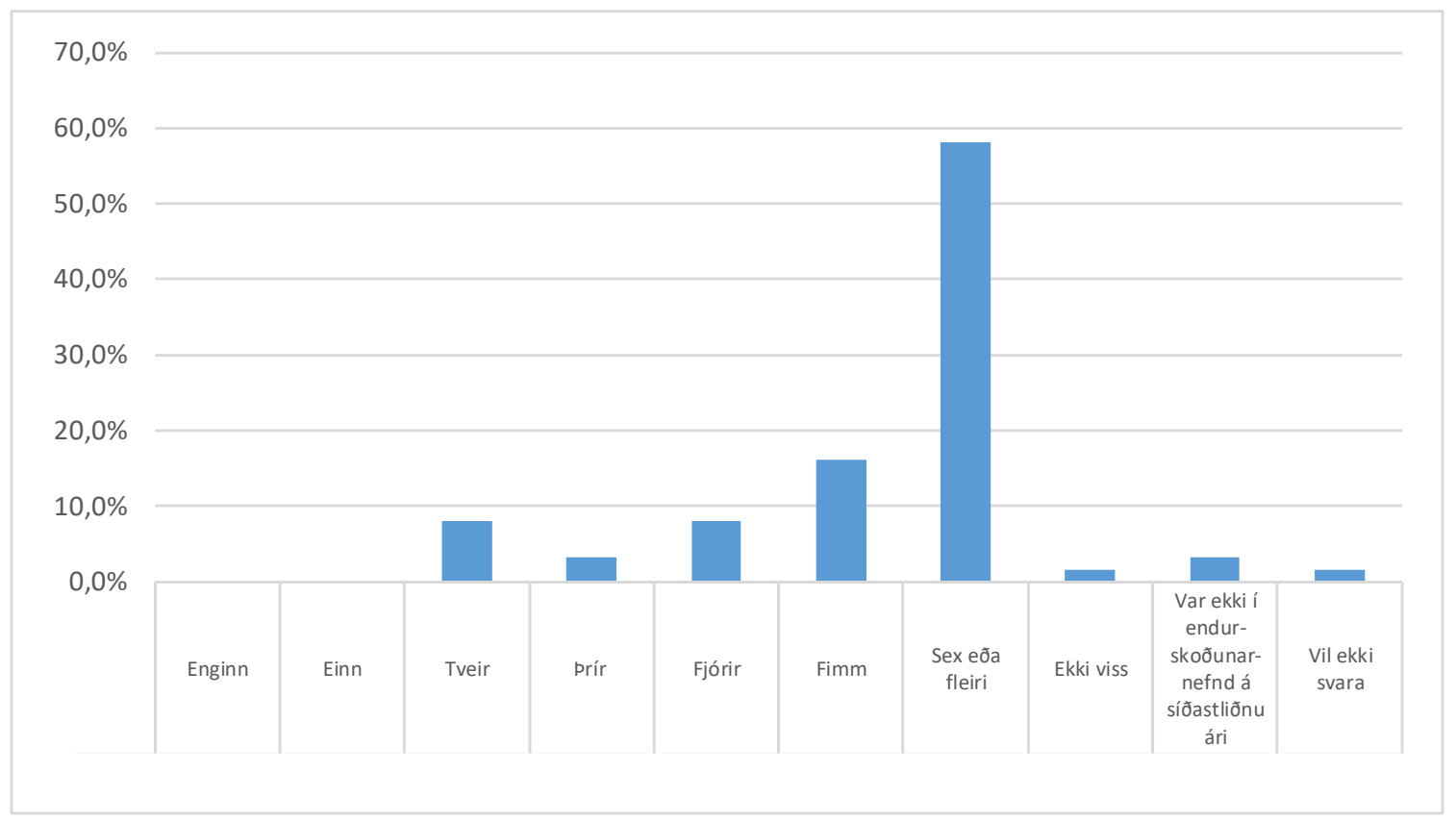

Mynd 1. Hver var fjöldi nefndarfunda ásíðastliðnu rekstrarári (kjörtímabili endurskoðunarnefndar)? 
Á mynd 1 kemur fram að um 11\% peirra sem svöruðu héldu prjá eða færri fundi á síðastliðnu rekstrarári. Rúmlega $22 \%$ voru með fjóra til fimm fundi og um $58 \%$ voru með sex fundi eða fleiri. Um 3\% voru ekki viss eða vildu ekki svara og 4\% voru ekki í endurskoðunarnefnd árið áður. Að meðaltali voru haldnir 5,2 fundir í endurskoðunarnefnd á ári. Ekki var spurt um tímasetningu fundanna. Ef endurskoðunarnefnd heldur alla fundi í desember og janúar verður sýnileikinn ekki eins mikill pví hina tíu mánuðina er enginn fundur. Samtals er hlutfall peirra sem hafa fimm eða fleiri nefndarfundi um $2 / 3$ peirra sem pátt tóku í könnuninni.

\subsection{Fundir með endurskoðanda}

Formaður endurskoðunarnefndar er sá aðili sem boðar fundi og einnig pátttakendur inn á fundi nefndarinnar. Ytri endurskoðandi er einn peirra sem endurskoðunarnefnd á að funda með að lágmarki einu sinni á ári. Pá er ekki gert ráð fyrir pví að yfirmenn einingarinnar séu viðstaddir.

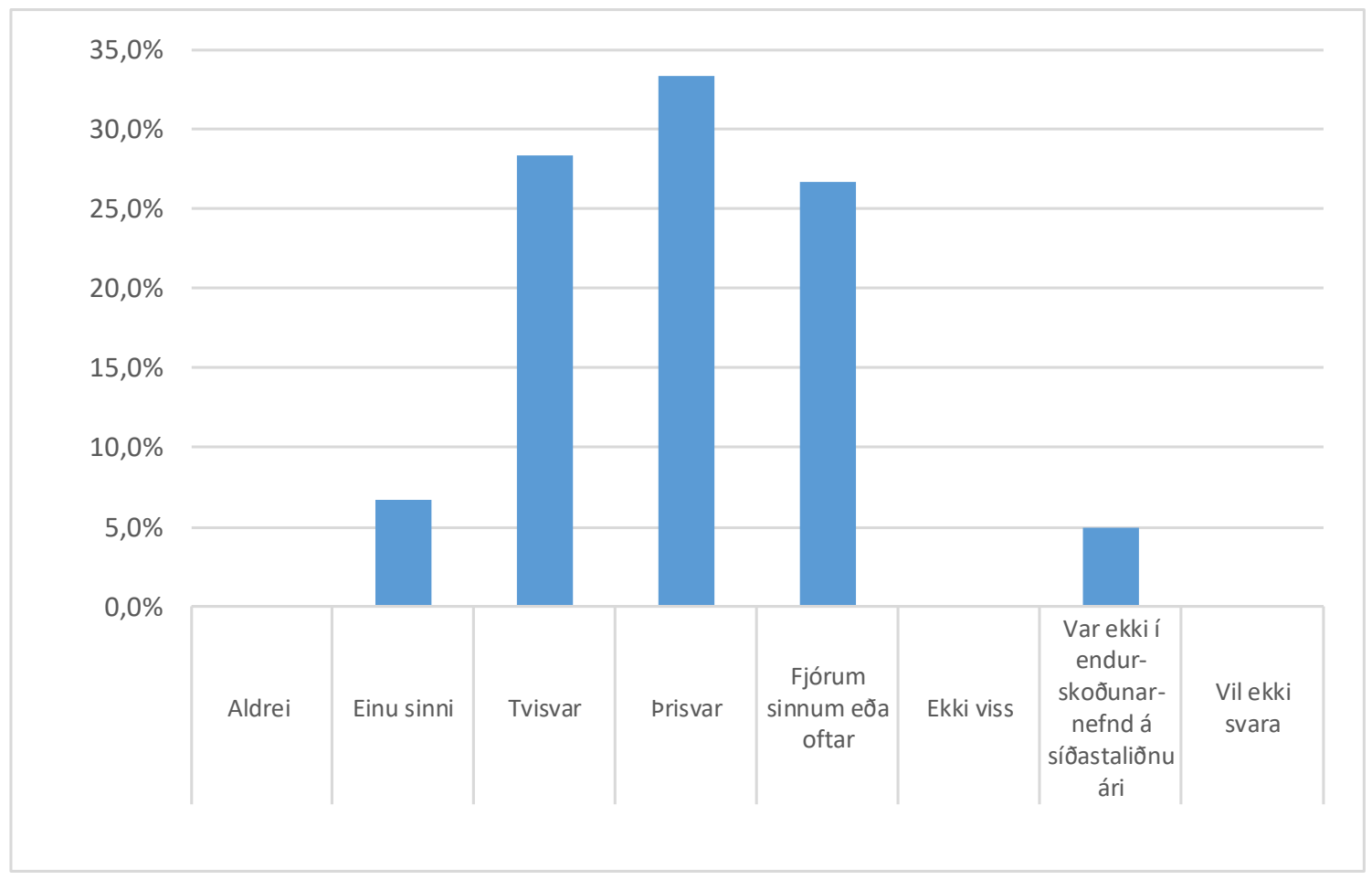

Mynd 2. Hversu oft fundaði endurskoðunarnefnd með ytri endurskoðanda á síðastliðnu rekstrarári/kjörtímabili?

Á mynd 2 kemur fram að tæplega 7\% pátttakenda höfðu fundað einu sinni með ytri endurskoðanda. Rúmlega 28\% höfðu fundað tvisvar og rúmlega 33\% prisvar. Er pað nokkuð oftar en ráðlegging frá FRC, 2012, gerir ráð fyrir. FRC gerir ráð fyrir að einn fundur sé pað lágmark sem endurskoðunarnefnd og ytri endurskoðandi skulu funda án stjórnenda félagsins. En einnig ráðleggur FRC að endurskoðunarteymi, stjórnandi og yfirmenn fjármála séu reglulega boðaðir á fund nefndarinnar. Í tilskipun EU, 537/2014, kemur fram að umræður skulu eiga sér stað varðandi meginniðurstöður endurskoðunar. Petta pýðir að einn fundur er haldinn með endurskoðanda eftir að endurskoðun líkur en endurskoðunarnefnd ber að meta endurskoðunaráætlun og pví parf einnig að funda með endurskoðanda áður en endurskoðun hefst. Tæplega 27\% pátttakenda funduðu fjórum sinnum eða oftar með ytri endurskoðanda. Pessi fundartíðni er mun meiri en áðurnefnd ráðlegging gefur til kynna. 


\subsection{Fundargögn með nægjanlegum fyrirvara}

Раð er háð aðstæðum hvað telst vera nægjanlegur fyrirvari. Taka verður tillit til pess að flestallir nefndarmenn hafa annað aðalstarf. Nefndarvinnan er pví ekki aðalstarf (Einar Guðbjartsson og Jón Snorri Snorrason, 2017). Pví getur orðið togstreita á milli aðalstarfs og nefndarstarfs hvað varðar tíma. Nefndarmenn purfa að gefa sér tíma til að sinna nefndarstörfum. Umfang nefndarstarfs hefur vaxið síðustu árin. Mögulega parf annað starfið að víkja, hvað tíma varðar, á vissum álagstímum. Nægjanlegur fyrirvari er pví einstaklingsbundinn og fer eftir aðstæðum viðkomandi. Nefndarmenn meta hvort nægjanlegur fyrirvari hafi verið til staðar eða ekki.

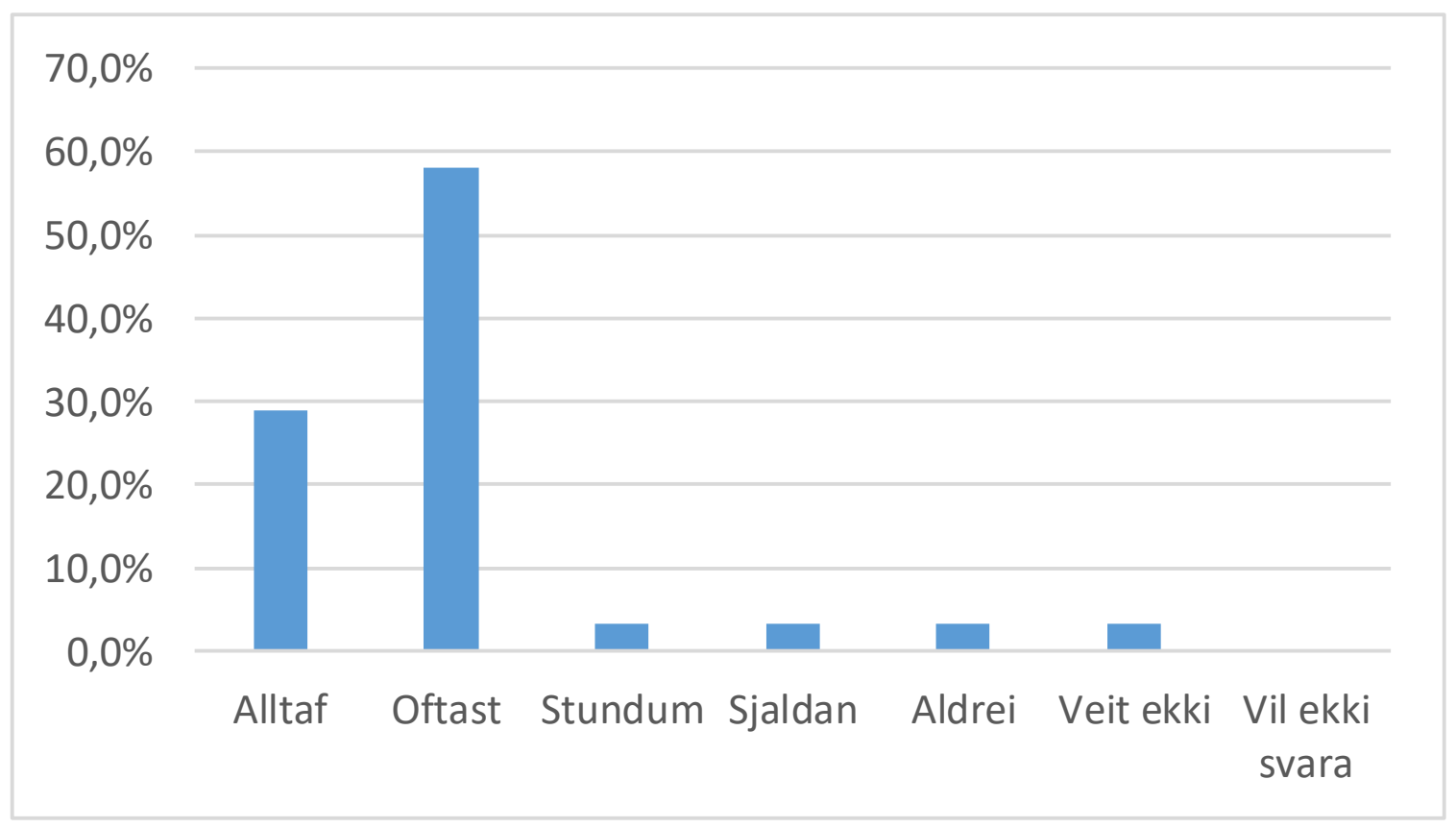

Mynd 3. Færð pú fundargögn með nægjanlegum fyrirvara til pess að geta sett pig inn í málefni næsta fundar?

Á mynd 3 kemur fram að tæplega 30\% segja að fundargögn hafi alltaf komið með nægjanlegum fyrirvara. Um 58\% segja að fundargögn komi oftast nær með nægjanlegum fyrirvara. Petta pýðir að undirbúningur hjá 58\% pátttakenda er ekki alltaf nægur og má áætla að umræða sem og virkni nefndarfunda verði ekki eins góð og annars hefði orðið, miðað við að fundargögn hefðu alltaf komið með nægjanlegum fyrirvara. Um 10\% pátttakenda telja að stundum, sjaldan eða aldrei komi nefndargögn með nægjanlegum fyrirvara. Petta er vísbending um að formaður purfi að bæta verkferla hvað varðar fundargögn. Ríflega $3 \%$ pátttakenda voru ekki vissir um pað hvort fundargögn hefðu borist með nægjanlegum fyrirvara eða ekki. Hér vaknar sú spurning hvort nefndarmenn geti lagt mat á pau fundargögn sem peim berast.

\subsection{Fundargögn fullnægjandi til að sinna nefndarstarfi}

Án fundargagna verður lítil virkni eða árangur af nefndarfundum. Hvaða fundargögn eru nauðsynleg fyrir hvern fund? Pessari spurningu er ekki alltaf auðvelt að svara. Að hluta til fer pað eftir skilningi og sérpekkingu nefndarmanna. Раð sem einum pykir nægjanlegt pykir öðrum kannski ekki nægjanlegt. Fundargögn verða að taka tillit til „lægsta samnefndara" í nefndinni, par sem aðilar hafa ekki sömu sýn, reynslu eða sérpekkingu á peim málefnum sem endurskoðunarnefnd ber að fjalla um og taka tillit til skv. lögum og erindisbréfi. 


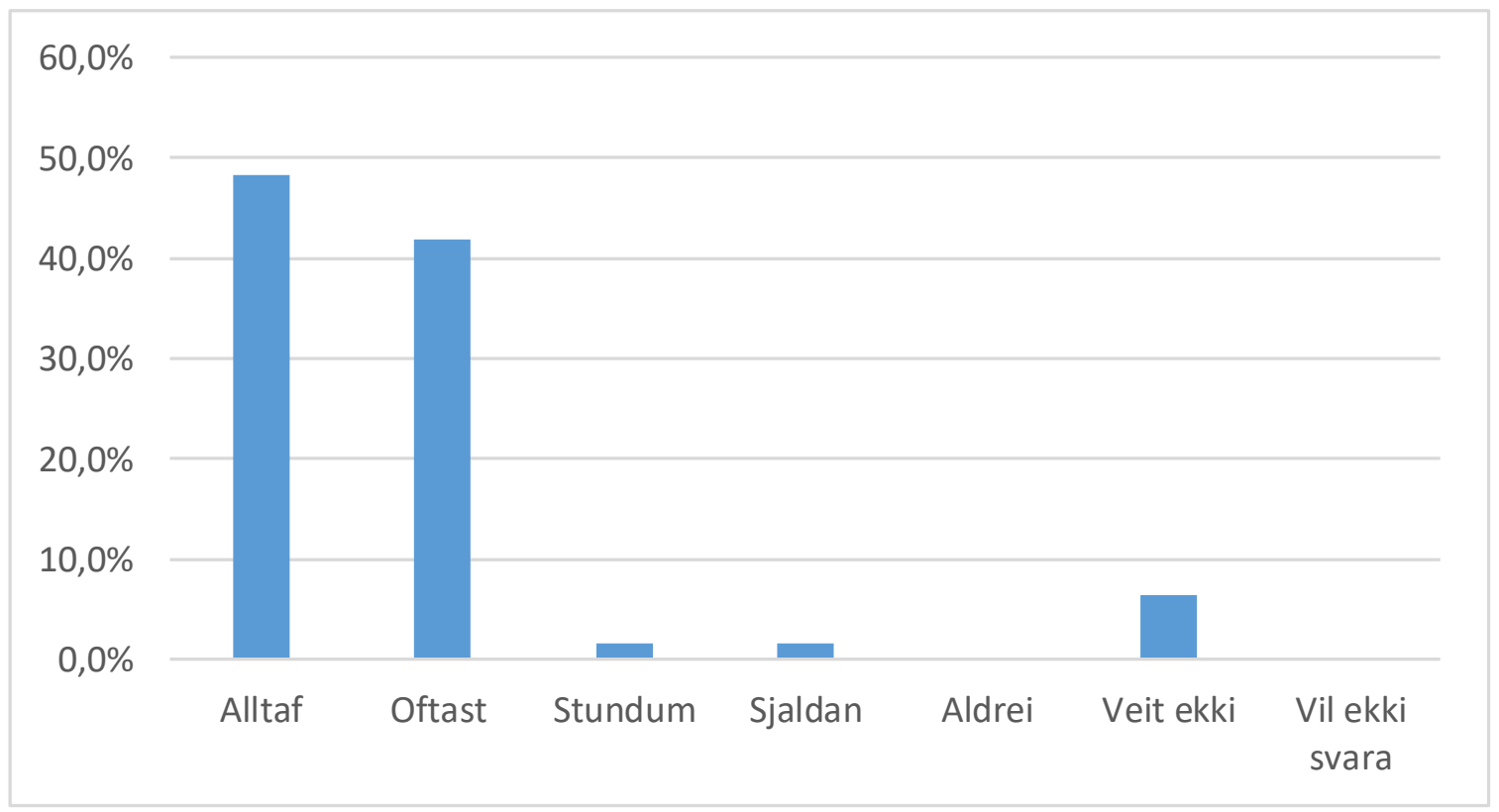

Mynd 4. Telur pú að pau fundargögn sem pú færð fyrir hvern fund séu fullnægjandi svo pú getir sinnt hlutverki pínu sem nefndarmaður?

Fram kemur í mynd 4 að um 48\% pátttakenda meta pað svo að fundargögn séu nægjanleg til pess að peir geti sinnt nefndarstarfi. Um $42 \%$ pátttakenda meta pað svo að fundargögn séu oftast pess eðlis að peir geti sinnt nefndarstarfi. Um 3\% svara stundum eða sjaldan. Petta bendir til pess að virkni pessara funda hefði i 45\% tilvika getað verið betri en raun var, að hluta til Um 6,5\% pátttakenda eru ekki vissir um hvort fundargögn hafi verið pess eðlis að nefndarmenn hafi getað sinnt nefndarstarfi sínu. Pessi niðurstaða dregur niður virkni fundar og par með virkni endurskoðunarnefnda.

\subsection{Eru virkar umræður á fundum?}

Virkar umræður leiða að öllum líkindum til pess að endurskoðunarnefndin sé virk í starfi sínu. Spurningar og gagnrýnar spurningar eru nauðsynlegar til að endurskoðunarnefnd sinni sínu starfi. Gefnar hafa verið út margar handbækur fyrir endurskoðunarnefndir, bæði af fagsamtökum og fagaðilum. Að leggja sjálfstætt mat á atriði eða skoðun óháð niðurstöðu ytri endurskoðanda er að vissu leyti gagnrýn spurning. Vitandi pað að formaður endurskoðunarnefndar purfi að mæti hluthöfum á aðalfundi og svara spurningum gerir pað af verkum að gagnrýnar spurningar verða venja frekar en undantekning á nefndarfundum. 


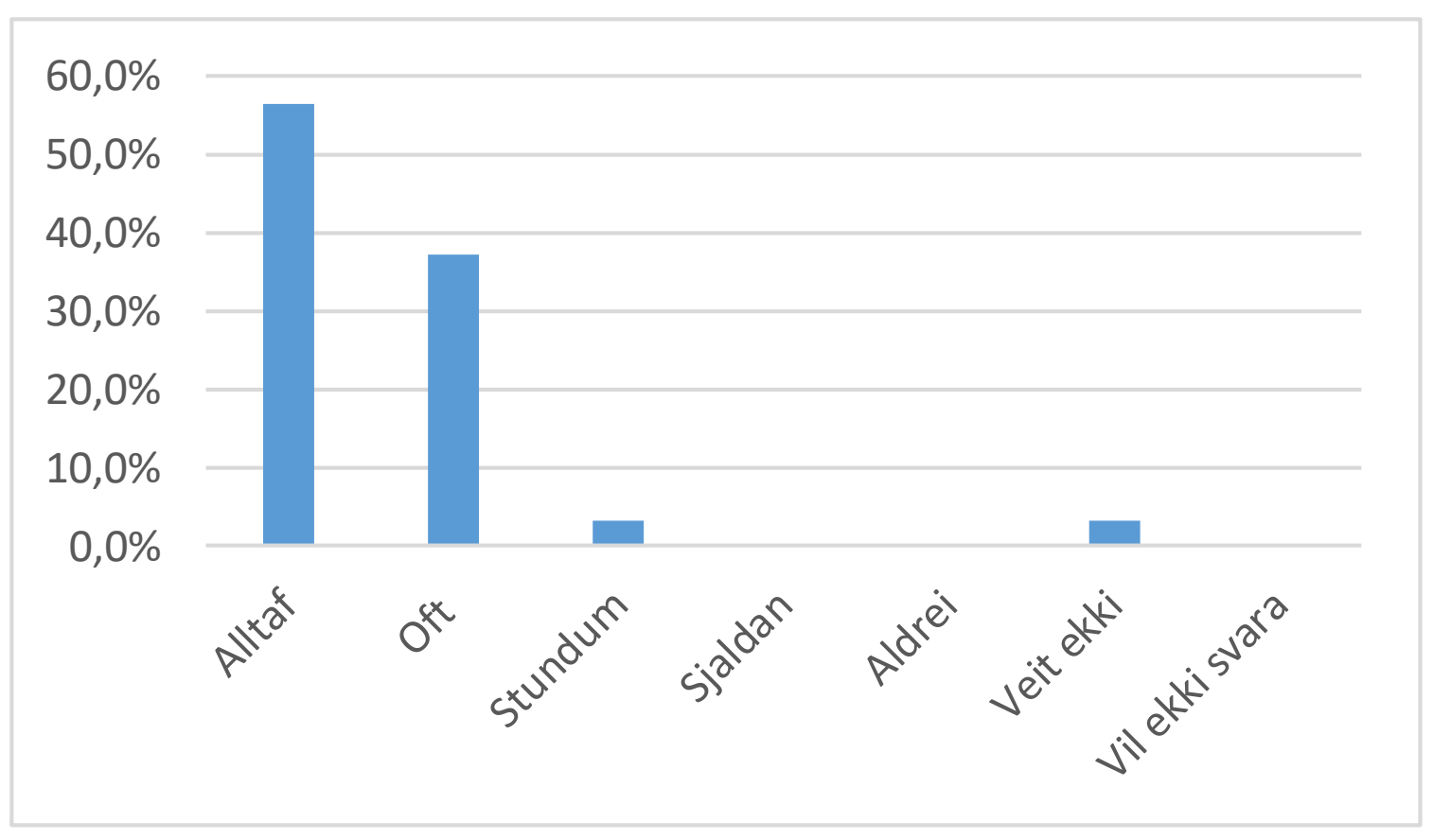

Mynd 5. Eru virkar umræður á fundum par sem bornar eru upp gagnrýnar spurningar?

Tæplega 57\% pátttakenda, mynd 5, meta pað svo að virkar umræður séu um gagnrýnar spurningar. Í 37\% tilvika eru ekki alltaf virkar umræður pegar gagnrýnar spurningar eru bornar upp á nefndarfundum og pessu til viðbótar eru rúmlega 3\% sem segja að stundum séu virkar umræður. Rúmlega 3\% taka ekki afstöðu til spurningarinnar. Um 94\% pátttakenda segja að alltaf eða oft séu virkar umræður pegar gagnrýnar spurningar eru á dagskrá nefndar.

\subsection{Fjöldi nefndarfunda og gæði fundargagna}

Fjöldi nefndarfunda endurskoðunarnefnda, spurning nr. 1, er hér krosskeyrð saman við prjár spurningar um fundargögn og virkni umræðna, p.e. spurningar nr. 3, 4 og 5 . Hér er verið að skoða möguleg tengsl við breytuna fjöldi nefndarfunda.

Í spurningunum um gæði fundargagna var notaður skali með hugtökum; alltaf, oftast, stundum, sjaldan, aldrei, veit ekki og vil ekki svara. Pessum hugtökum er endurraðað og skipt í prjá flokka, „viðunandi“, „ekki viðunandi“ og „ekkert svar“. Hugtökin alltaf og oftast flokkast i „,viðunandi“. Hugtökin stundum, sjaldan, aldrei og veit ekki flokkast í „,ekki viðunandi“. Hugtakið vil ekki svara flokkast í „ekkert svar“. Ekki var spurt um ástæðu pess að viðkomandi merkti við vil ekki svara. Mögulega getur verið að viðkomandi sé nýr í endurskoðunarnefnd.

Hver var fjöldi nefndarfunda á síðastliðnu rekstrarári (kjörtímabili endurskoðunarnefndar)?

Í priðju spurningunni var spurt um hvort fundargögn hefðu borist nefndarmanni með nægjanlegum fyrirvara með tilliti til málefna næsta fundar. 
Tafla 1. Krosskeyrsla á spurningum nr. 1 og nr. 3.

Færð pú fundargögn með nægjanlegum fyrirvara til pess að geta sett pig inn i málefni næsta fundar?

\begin{tabular}{|c|c|c|c|c|c|c|c|c|c|c|c|}
\hline & Heild & Enginn & Einn & Tveir & Prír & Fjórir & Fimm & $\begin{array}{r}\text { Sex eða } \\
\text { fleiri }\end{array}$ & Ekki viss & $\begin{array}{r}\text { Var ekki í } \\
\text { endur- } \\
\text { skoðunar- } \\
\text { nefnd á } \\
\text { síðastliðnu } \\
\text { ári }\end{array}$ & $\begin{array}{r}\text { Vil ekki } \\
\text { svara }\end{array}$ \\
\hline \begin{tabular}{|l|} 
Viðunandi \\
\end{tabular} & $87,1 \%$ & $0,0 \%$ & $0,0 \%$ & $60,0 \%$ & $50,0 \%$ & $100,0 \%$ & $100,0 \%$ & $88,9 \%$ & $100,0 \%$ & $50,0 \%$ & $100,0 \%$ \\
\hline Ekki viðunandi & $12,9 \%$ & $0,0 \%$ & $0,0 \%$ & $40,0 \%$ & $50,0 \%$ & $0,0 \%$ & $0,0 \%$ & $11,1 \%$ & $0,0 \%$ & $50,0 \%$ & $0,0 \%$ \\
\hline Ekkert svar & $0,0 \%$ & $0,0 \%$ & $0,0 \%$ & $0,0 \%$ & $0,0 \%$ & $0,0 \%$ & $0,0 \%$ & $0,0 \%$ & $0,0 \%$ & $0,0 \%$ & $0,0 \%$ \\
\hline
\end{tabular}

Eins og fram kemur í töflu 1 voru svör helmings peirra nefndarmanna sem höfðu prjá nefndarfundi pess eðlis að pau voru flokkuð sem ekki viðunandi. Svör $40 \%$ peirra nefndarmanna sem höfðu tvo nefndarfundi voru pess eðlis að pau voru flokkuð sem ekki viðunandi. Nefndarmenn sem svöruðu að nefndarfundirnir væru sex eða fleiri voru $11,1 \%$ og svör peirra pess eðlis að pau voru flokkuð sem ekki viðunandi. Par sem nefndarfundir voru fjórir eða fimm flokkuðust öll svör nefndarmanna sem viðunandi. Engin endurskoðunarnefnd hélt einungis einn fund.

Í kí kvaðratprófi var niðurstaðan sú að kí kvaðratgildið var 7.1107 og $p$ gildið var 0.007663 Petta er pví marktækt með $p<.05$.

Tafla 1a. Kí kvaðratpróf, spurningar nr. 1 og nr. 4.

\begin{tabular}{|c|c|c|c|}
\hline & $\begin{array}{l}\begin{array}{l}\text { Fjöldi nefndarfunda, } \\
\text { prír eða færri. }\end{array} \\
\end{array}$ & $\begin{array}{l}\begin{array}{l}\text { Fjöldi nefndarfunda, } \\
\text { fjórir eða fleiri. }\end{array} \\
\end{array}$ & Samtals \\
\hline Viðunandi & $\begin{array}{lll}4 & (6,16) & {[0,75]} \\
\end{array}$ & $\begin{array}{lll}47 & (44,84) & {[0,10]} \\
\end{array}$ & 51 \\
\hline Ekki viðunandi & $3 \quad(0,84) \quad[5,50]$ & $4 \quad(6,16) \quad[0,75]$ & 7 \\
\hline Samtals & 7 & 51 & 58 \\
\hline
\end{tabular}

Par sem sum gildi voru lægri en fimm einingar pá var Fisher's exact test gert til að athuga hvort önnur niðurstaða fengist. Svo reyndist ekki vera, Fisher's exact test gildið var 0.0316 og er marktækt miðað við $p<.05$. Kí kvaðratpróf samkvæmt Yates leiðréttingu breytir ekki niðurstöðunni.

Í spurningu fjögur var spurt um hvort pau fundargögn sem nefndarmaður fékk hafi verið pess eðlis að viðkomandi hafi getað sinnt hlutverki sínu sem nefndarmaður. Рað er nauðsynlegt að fá pau fundargögn sem parf til pess að taka afstöðu til ákveðinna viðfangsefna.

Tafla 2. Krosskeyrsla á spurningum nr. 1 og nr. 4.

Telur pú að pau fundargögn sem pú færð fyrir hvern fund séu fullnægjandi svo pú getir sinnt hlutverki pinu sem nefndarmaður?

\begin{tabular}{|c|c|c|c|c|c|c|c|c|c|c|c|}
\hline & Heild & Enginn & Einn & Tveir & Prír & Fjórir & Fimm & $\begin{array}{r}\text { Sex eða } \\
\text { fleiri }\end{array}$ & Ekki viss & $\begin{array}{r}\text { Var ekki í } \\
\text { endur- } \\
\text { skoðunar- } \\
\text { nefnd á } \\
\text { síðastliðnu } \\
\text { ári }\end{array}$ & $\begin{array}{r}\text { Vil ekki } \\
\text { svara } \\
\end{array}$ \\
\hline Viðunandi & $90,3 \%$ & $0,0 \%$ & $0,0 \%$ & $100,0 \%$ & $50,0 \%$ & $100,0 \%$ & $100,0 \%$ & $91,7 \%$ & $100,0 \%$ & $0,0 \%$ & $100,0 \%$ \\
\hline Ekki viðunandi & $9,7 \%$ & $0,0 \%$ & $0,0 \%$ & $0,0 \%$ & $50,0 \%$ & $0,0 \%$ & $0,0 \%$ & $8,3 \%$ & $0,0 \%$ & $100,0 \%$ & $0,0 \%$ \\
\hline Ekkert svar & $0,0 \%$ & $0,0 \%$ & $0,0 \%$ & $0,0 \%$ & $0,0 \%$ & $0,0 \%$ & $0,0 \%$ & $0,0 \%$ & $0,0 \%$ & $0,0 \%$ & $0,0 \%$ \\
\hline
\end{tabular}

Eins og fram kemur í töflu 2 voru svör helmings peirra nefndarmanna sem höfðu prjá nefndarfundi pess eðlis að pau voru flokkuð sem ekki viðunandi. Nefndarmenn sem svöruðu að nefndarfundirnir hefðu verið sex eða fleiri voru 8,3\% og svör peirra pess eðlis að pau voru flokkuð sem ekki viðunandi. Par sem nefndarfundir voru tveir, fjórir eða fimm flokkuðust öll svör nefndarmanna sem viðunandi. Nefndarmenn sem ekki voru í endurskoðunarnefnd á síðastliðnu ári svöruðu á pann hátt að svör peirra flokkuðust sem ekki viðunandi. 
Í kí kvaðratprófi var niðurstaðan sú að k í kvaðratgildið var 0.6769 og $p$ gildið var 0.410643. Petta er ekki marktækt miðað við $p<.05$.

Tafla 2a. Kí kvaðratpróf, spurningar nr. 1 og nr. 3.

\begin{tabular}{|c|c|c|c|}
\hline & $\begin{array}{l}\text { Fjöldi nefndarfunda, } \\
\text { prír eða færri. }\end{array}$ & $\begin{array}{l}\text { Fjöldi nefndarfunda, } \\
\text { fjórir eða fleiri. }\end{array}$ & Samtals \\
\hline Viðunandi & $6 \quad(6,52) \quad[0,04]$ & $48 \quad(47,48) \quad[0,01]$ & 54 \\
\hline Ekki viðunandi & $\begin{array}{lll}1 & (0,48) & {[0,55]}\end{array}$ & $3(3,52) \quad[0,08]$ & 4 \\
\hline Samtals & 7 & 51 & 58 \\
\hline
\end{tabular}

Par sem sum gildi voru lægri en fimm einingar pá var Fisher's exact test gert til að athuga hvort önnur niðurstaða fengist. Svo reyndist ekki vera, Fisher's exact test gildið var 0.411. Kí kvaðratpróf samkvæmt Yates leiðréttingu breytir ekki niðurstöðunni.

Í fimmtu spurningunni er spurt um virkar umræður pegar gagnrýnar spurningar eru bornar upp á nefndarfundum. Umræður eru mjög mikilvægur páttur í pví ferli að virkni endurskoðunarnefnda náist og viðhaldist.

Tafla 3. Krosskeyrsla á spurningum nr. 1 og nr. 5.

Eru virkar umræður á fundum par sem bornar eru upp gagnrýnar spurningar?

\begin{tabular}{|c|c|c|c|c|c|c|c|c|c|c|c|}
\hline & Heild & Enginn & Einn & Tveir & Prír & Fjórir & Fimm & $\begin{array}{r}\text { Sex eða } \\
\text { fleiri }\end{array}$ & Ekki viss & $\begin{array}{r}\text { Var ekki í } \\
\text { endur- } \\
\text { skoðunar- } \\
\text { nefnd á } \\
\text { síðastliðnu } \\
\text { ári }\end{array}$ & $\begin{array}{r}\text { Vil ekki } \\
\text { svara }\end{array}$ \\
\hline Viðunandi & $93,5 \%$ & $0,0 \%$ & $0,0 \%$ & $80,0 \%$ & $100,0 \%$ & $100,0 \%$ & $100,0 \%$ & $94,4 \%$ & $100,0 \%$ & $50,0 \%$ & $100,0 \%$ \\
\hline Ekki viðunandi & $6,5 \%$ & $0,0 \%$ & $0,0 \%$ & $20,0 \%$ & $0,0 \%$ & $0,0 \%$ & $0,0 \%$ & $5,6 \%$ & $0,0 \%$ & $50,0 \%$ & $0,0 \%$ \\
\hline Ekkert svar & $0,0 \%$ & $0,0 \%$ & $0,0 \%$ & $0,0 \%$ & $0,0 \%$ & $0,0 \%$ & $0,0 \%$ & $0,0 \%$ & $0,0 \%$ & $0,0 \%$ & $0,0 \%$ \\
\hline
\end{tabular}

Eins og fram kemur í töflu 3 voru svör 20\% peirra nefndarmanna sem höfðu tvo nefndarfundi pess eðlis að pau voru flokkuð sem ekki viðunandi. Nefndarmenn sem svöruðu að nefndarfundirnir hefðu verið sex eða fleiri voru 5,6\% og svör peirra pess eðlis að pau voru flokkuð sem ekki viðunandi. Svör frá helmingi peirra nefndarmanna sem ekki voru í endurskoðunarnefnd á síðastliðnu ári voru pess eðlis að pau voru flokkuð sem ekki viðunandi. Par sem nefndarfundir voru prír, fjórir eða fimm flokkuðust öll svör nefndarmanna sem viðunandi.

Í kí kvaðratprófi var niðurstaðan sú að kí kvaðratgildið var 1.348 og $p$ gildið var 0.245634. petta er ekki marktækt miðað við $p<.05$.

Tafla 3a. Kí kvaðratpróf, spurningar nr. 1 og nr. 5.

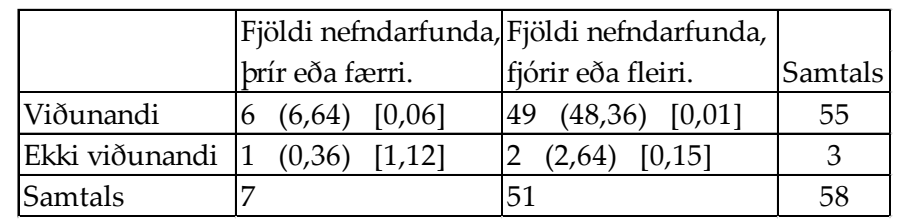

Par sem sum gildi voru lægri en fimm einingar pá var Fisher's exact test gert til að athuga hvort önnur niðurstaða fengist. Svo reyndist ekki vera, Fisher's exact test gildið var 0.3251 og er ekki marktækt miðað við $p<.05$. Kí kvaðratpróf samkvæmt Yates leiðréttingu breytir ekki niðurstöðunni.

\subsection{Fjöldi funda með endurskoðanda og gæði fundargagna}

Fjöldi funda endurskoðunarnefnda með ytri endurskoðanda, spurning nr. 2, er hér borin saman við prjár spurningar, p.e. spurningar nr. 3, 4 og 5. Spurning nr. 2 er krosskeyrð 
til pess að athuga hvort fjöldi funda endurskoðunarnefnda með ytri endurskoðanda hafi mögulega tengsl við gæði fundargagna.

I spurningunum um gæði fundargagna var notaður skali með hugtökunum alltaf, oftast, stundum, sjaldan, aldrei, veit ekki og vil ekki svara. Pessum hugtökum er endurraðað og skipt í prjá flokka, „,viðunandi“, „ekki viðunandi“ og "ekkert svar“. Hugtökin alltaf og oftast flokkast í „viðunandi“. Hugtökin stundum, sjaldan, aldrei og veit ekki flokkast í „ekki viðunandi“. Hugtakið vil ekki svara flokkast í „ekkert svar". Ekki var spurt um ástæðu pess að viðkomandi merkti við vil ekki svara. Mögulega getur verið að viðkomandi sé nýr í endurskoðunarnefnd.

Hversu oft fundaði endurskoðunarnefnd með y tri endurskoðanda á síðastliðnu rekstrarári/kjörtímabili?

Í priðju spurningunni var spurt um hvort fundargögn hefðu borist nefndarmanni með nægjanlegum fyrirvara með tillit til nefndarstarfa.

Tafla 4. Krosskeyrsla á spurningum nr. 2 og nr. 3.

Færð pú fundargögn með nægjanlegum fyrirvara til pess að geta sett pig inn í málefni næsta fundar?

\begin{tabular}{|c|c|c|c|c|c|c|c|c|c|}
\hline & Heild & $\begin{array}{l}\text { Enginn } \\
\text { fundur }\end{array}$ & $\begin{array}{r}\text { Einn } \\
\text { fundur }\end{array}$ & $\begin{array}{r}\text { Tveir } \\
\text { fundir }\end{array}$ & Prír fundir & $\begin{array}{r}\text { Fjórir } \\
\text { fundir eða } \\
\text { fleiri }\end{array}$ & Ekki viss & \begin{tabular}{|r|} 
Var ekki í \\
endur- \\
skoðunar- \\
nefnd á \\
síðastliðnu \\
ári \\
\end{tabular} & $\begin{array}{r}\text { Vil ekki } \\
\text { svara } \\
\end{array}$ \\
\hline Viðunandi & $86,7 \%$ & $0,0 \%$ & $75,0 \%$ & $88,2 \%$ & $95,0 \%$ & $87,5 \%$ & $0,0 \%$ & $33,3 \%$ & $0,0 \%$ \\
\hline Ekki viðunandi & $13,3 \%$ & $0,0 \%$ & $25,0 \%$ & $11,8 \%$ & $5,0 \%$ & $12,5 \%$ & $0,0 \%$ & $66,7 \%$ & $0,0 \%$ \\
\hline Ekkert svar & $0,0 \%$ & $0,0 \%$ & $0,0 \%$ & $0,0 \%$ & $0,0 \%$ & $0,0 \%$ & $0,0 \%$ & $0,0 \%$ & $0,0 \%$ \\
\hline
\end{tabular}

Eins og fram kemur í töflu 4 voru svör 25\% peirra nefndarmanna par sem endurskoðunarnefnd hélt einn fund með endurskoðanda pess eðlis að pau voru flokkuð sem ekki viðunandi. Svör 11,8\% peirra nefndarmanna par sem endurskoðunarnefnd hélt tvo fundi með endurskoðanda voru pess eðlis að pau voru flokkuð sem ekki viðunandi. Svör 5,0\% peirra nefndarmanna par sem endurskoðunarnefnd hélt prjá fundi með endurskoðanda voru pess eðlis að pau voru flokkuð sem ekki viðunandi. Útkoman hér var sú að ekki viðunandi svörum fór fækkandi eftir pví sem fundum með endurskoðanda fjölgaði. En pessi útkoma tekur aðra stefnu pegar skoðuð voru svör nefndarmanna sem héldu fjóra fundi eða fleiri með endurskoðanda. $12,5 \%$ svara voru pess eðlis að pau voru flokkuð sem ekki viðunandi. Svör frá 2/3 hluta peirra nefndarmanna sem ekki voru í endurskoðunarnefnd á síðastliðnu ári voru pess eðlis að pau voru flokkuð sem ekki viðunandi, en að öllum líkindum hafa pessir aðilar ekki setið fund með endurskoðanda.

Í kí kvaðratprófi var niðurstaðan sú að kí kvaðratgildið var 0.0254 og $p$ gildið var 0.873475. Petta er ekki marktækt miðað við $p<.05$.

Tafla 4a. Kí kvaðratpróf, spurningar nr. 2 og nr. 3.

\begin{tabular}{|l|l|l|c|}
\hline & $\begin{array}{l}\text { Fjöldi funda með } \\
\text { ytri endurskoðanda, } \\
\text { tveir eða færri. }\end{array}$ & $\begin{array}{l}\text { Fjöldi funda með } \\
\text { ytri endurskoðanda, } \\
\text { prír eða fleiri. }\end{array}$ & Samtals \\
\hline Viðunandi & $\begin{array}{l}18(18,20) \quad[0,00] \\
34(33,80)\end{array}[0,00]$ & 52 \\
\hline Ekki viðunandi & $3(2,80)[0,01]$ & $5(5,20)[0,01]$ & 8 \\
\hline Samtals & 21 & 39 & 60 \\
\hline
\end{tabular}

Par sem sum gildi voru lægri en fimm einingar pá var Fisher's exact test gert til að athuga hvort önnur niðurstaða fengist. Svo reyndist ekki vera, Fisher's exact test gildið var 1.0 og er ekki marktækt miðað við $p<.05$. Kí kvaðratpróf samkvæmt Yates leiðréttingu breytir ekki niðurstöðunni. 
Í spurningu fjögur var spurt um hvort pau gögn sem nefndarmaður fékk hafi verið pess eðlis að viðkomandi gæti sinnt hlutverki sínu sem nefndarmaður. Nauðsynlegt er að fá öll pau gögn sem parf til pess að taka afstöðu til viðfangsefna og pannig sinnt starfsskyldum sínum.

Tafla 5. Krosskeyrsla á spurningum nr. 2 og nr. 4.

Telur pú að pau fundargögn sem pú færð fyrir hvern fund séu fullnægjandi svo pú getir sinnt hlutverki pínu sem nefndarmaður?

\begin{tabular}{|c|c|c|c|c|c|c|c|c|c|}
\hline & Heild & $\begin{array}{l}\text { Enginn } \\
\text { fundur }\end{array}$ & $\begin{array}{r}\text { Einn } \\
\text { fundur }\end{array}$ & $\begin{array}{r}\text { Tveir } \\
\text { fundir }\end{array}$ & Drír fundir & \begin{tabular}{|r} 
Fjórir \\
fundir eða \\
fleiri
\end{tabular} & Ekki viss & $\begin{array}{r}\text { Var ekki í } \\
\text { endur- } \\
\text { skoðunar- } \\
\text { nefnd á } \\
\text { síðastliðnu } \\
\text { ári }\end{array}$ & $\begin{array}{r}\text { Vil ekki } \\
\text { svara }\end{array}$ \\
\hline Viðunandi & $90,0 \%$ & $0,0 \%$ & $75,0 \%$ & $100,0 \%$ & $95,0 \%$ & $93,8 \%$ & $0,0 \%$ & $0,0 \%$ & $0,0 \%$ \\
\hline Ekki viðunandi & $10,0 \%$ & $0,0 \%$ & $25,0 \%$ & $0,0 \%$ & $5,0 \%$ & $6,3 \%$ & $0,0 \%$ & $100,0 \%$ & $0,0 \%$ \\
\hline Ekkert svar & $0,0 \%$ & $0,0 \%$ & $0,0 \%$ & $0,0 \%$ & $0,0 \%$ & $0,0 \%$ & $0,0 \%$ & $0,0 \%$ & $0,0 \%$ \\
\hline
\end{tabular}

Eins og fram kemur í töflu 5 voru svör 25\% peirra nefndarmanna par sem endurskoðunarnefnd hélt einn fund með endurskoðanda pess eðlis að pau voru flokkuð sem ekki viðunandi. Svör 5,0\% peirra nefndarmanna par sem endurskoðunarnefnd hélt prjá fundi með endurskoðanda voru pess eðlis að pau voru flokkuð sem ekki viðunandi. Svör nefndarmanna sem héldu fjóra fundi eða fleiri með endurskoðanda voru pess eðlis að 6,3\% voru flokkuð sem ekki viðunandi. Svör frá öllum peim nefndarmönnum sem ekki voru í endurskoðunarnefnd á síðastliðnu ári voru pess eðlis að pau voru flokkuð sem ekki viðunandi, en að öllum líkindum hafa pessir aðilar ekki setið fund með endurskoðanda.

Í kí kvaðratprófi var niðurstaðan sú að kí kvaðratgildið var 0.9849 og $p$ gildið var 0.320982. Petta er ekki marktækt miðað við $p<.05$.

Tafla 5a. Kí kvaðratpróf, spurningar nr. 2 og nr. 4.

\begin{tabular}{|c|c|c|c|}
\hline & $\begin{array}{l}\text { Fjöldi funda með } \\
\text { ytri endurskoðanda, } \\
\text { tveir eða færri. }\end{array}$ & $\begin{array}{l}\text { Fjöldi funda með } \\
\text { ytri endurskoðanda, } \\
\text { prír eða fleiri. }\end{array}$ & Samtals \\
\hline Viðunandi & $20 \quad(18,90) \quad[0,06]$ & $34 \quad(35,10) \quad[0,03]$ & 54 \\
\hline Ekki viðunandi & $1 \quad(2,10) \quad[0,58]$ & $\begin{array}{lll}5 & (3,90) & {[0,31]}\end{array}$ & 6 \\
\hline Samtals & 21 & 39 & 60 \\
\hline
\end{tabular}

Par sem sum gildi voru lægri en fimm einingar pá var Fisher's exact test gert til að athuga hvort önnur niðurstaða fengist. Svo reyndist ekki vera, Fisher's exact test gildið var 0.4122 og er ekki marktækt miðað við $p<.05$. Kí kvaðratpróf samkvæmt Yates leiðréttingu breytir ekki niðurstöðunni.

Í fimmtu spurningu er spurt um virkar umræður pegar gagnrýnar spurningar eru bornar upp á nefndarfundum.

Tafla 6. Krosskeyrsla á spurningum nr. 2 og nr. 5.

Eru virkar umræður á fundum par sem bornar eru upp gagnrýnar spurningar?

\begin{tabular}{|c|c|c|c|c|c|c|c|c|c|}
\hline & Heild & $\begin{array}{l}\text { Enginn } \\
\text { fundur }\end{array}$ & $\begin{array}{r}\text { Einn } \\
\text { fundur }\end{array}$ & $\begin{array}{l}\text { Tveir } \\
\text { fundir }\end{array}$ & Prír fundir & $\begin{array}{r}\text { Fjórir } \\
\text { fundir eða } \\
\text { fleiri }\end{array}$ & Ekki viss & $\begin{array}{r}\text { Var ekki í } \\
\text { endur- } \\
\text { skoðunar- } \\
\text { nefnd á } \\
\text { síðastliðnu } \\
\text { ári }\end{array}$ & $\begin{array}{r}\text { Vil ekki } \\
\text { svara }\end{array}$ \\
\hline Viðunandi & $93,3 \%$ & $0,0 \%$ & $75,0 \%$ & $94,1 \%$ & $100,0 \%$ & $100,0 \%$ & $0,0 \%$ & $33,3 \%$ & $0,0 \%$ \\
\hline Ekki viðunandi & $6,7 \%$ & $0,0 \%$ & $25,0 \%$ & $5,9 \%$ & $0,0 \%$ & $0,0 \%$ & $0,0 \%$ & $66,7 \%$ & $0,0 \%$ \\
\hline Ekkert svar & $0,0 \%$ & $0,0 \%$ & $0,0 \%$ & $0,0 \%$ & $0,0 \%$ & $0,0 \%$ & $0,0 \%$ & $0,0 \%$ & $0,0 \%$ \\
\hline
\end{tabular}


Eins og fram kemur í töflu 6 voru svör peirra 25\% nefndarmanna par sem endurskoðunarnefnd hélt einn fund með endurskoðanda pess eðlis að pau voru flokkuð sem ekki viðunandi. Svör 5,9\% nefndarmanna par sem endurskoðunarnefnd hélt tvo fundi með endurskoðanda voru pess eðlis að pau voru flokkuð sem ekki viðunandi. Svör nefndarmanna sem héldu prjá eða fjóra fundi eða fleiri með endurskoðanda voru pess eðlis að engin svör voru flokkuð sem ekki viðunandi. Svör frá 2/3 hluta peirra nefndarmanna sem ekki voru í endurskoðunarnefnd á síðastliðnu ári voru pess eðlis að pau voru flokkuð sem ekki viðunandi, en að öllum líkindum hafa pessi aðilar ekki setið fund með endurskoðanda.

Í kí kvaðratprófi var niðurstaðan sú að kí kvaðratgildið var 0.4239 og $p$ gildið var 0.515016. Petta er ekki marktækt miðað við $p<.05$.

Tafla 6a. Kí kvaðratpróf, spurningar nr. 2 og nr. 5.

\begin{tabular}{|c|c|c|c|}
\hline & $\begin{array}{l}\text { Fjöldi funda með } \\
\text { ytri endurskoðanda, } \\
\text { tveir eða færri. }\end{array}$ & $\begin{array}{l}\text { Fjöldi funda með } \\
\text { ytri endurskoðanda, } \\
\text { prír eða fleiri. }\end{array}$ & Samtals \\
\hline Viðunandi & $19 \quad(19,60) \quad[0,02]$ & $\begin{array}{lll}37 & (33,40) & {[0,01]}\end{array}$ & 56 \\
\hline Ekki viðunandi & $2(1,40) \quad[0,26]$ & $\begin{array}{lll}2 & (2,60) & {[0,14]}\end{array}$ & 4 \\
\hline Samtals & 21 & 39 & 60 \\
\hline
\end{tabular}

Par sem sum gildi voru lægri en fimm einingar pá var Fisher's exact test gert til að athuga hvort önnur niðurstaða fengist. Svo reyndist ekki vera, Fisher's exact test gildið var 0.6064 og er ekki marktækt miðað við $p<.05$. Kí kvaðratpróf samkvæmt Yates leiðréttingu breytir ekki niðurstöðunni.

\subsection{Samantekt á niðurstöðum}

Nefndarfundir voru fimm eða fleiri hjá rúmlega 2/3 pátttakenda, mynd 1. Tæplega 20\% pátttakenda svöruðu pví til að nefndarfundir hefðu verið tveir til fjórir. Að meðaltali voru haldnir 5,2 nefndarfundir á ári. Um 60\% pátttakenda sögðu að endurskoðunarnefndirnar hefðu fundað prisvar eða oftar með ytri endurskoðanda, mynd 2. Um 35\% pátttakenda sögðu að fundað hefði verið með endurskoðanda einu sinni eða tvisvar. Pau svör sem fram koma við pessum spurningum virðast ekki vera í mótsögn, p.e. nefndarfundir eru fleiri en fundir með endurskoðanda. Hér fæst ákveðin heildarmynd af fundartíðni endurskoðunarnefnda í pví umhverfi sem spurningar ná til, bæði hvað varðar nefndarfundi og fundi með ytri endurskoðanda. Vakin er athygli á pví að gagnamagn er mun minna í íslensku umhverfi en í sambærilegu erlendu umhverfi, t.d. Norðurlönd, Bretland eða annað land í Evrópusambandinu.

Varðandi spurninguna hvort fundargögn komi með nægjanlegum fyrirvara pannig að viðkomandi geti sett sig inn í málefnin sem tekin verða fyrir á fundi, svöruðu tæplega $30 \%$ pátttakenda alltaf, mynd 3. Um 58\% svöruðu oftast. Par sem fundir eru að meðaltali 5,2 á ári má áætla að einn eða tveir af peim fundum beri pess merki að fundargögn komi ekki með nægjanlegum fyrirvara, eftir atvikum. Rúmlega $87 \%$ peirra sem svöruðu sögðu að fyrirvarinn væri alltaf eða oftast nægjanlegur. Í tæplega 13\% tilvika svöruðu pátttakendur stundum, sjaldan, aldrei eða veit ekki. Раð er í raun ekki viðunandi.

Ekki er deilt um pað að mikilvægt sé að fundargögn séu pannig útbúin að hver nefndarmaður geti sinnt hlutverki sínu. Tæplega $50 \%$ pátttakenda segja að fundargögn séu alltaf pannig útbúin að nefndarmenn geti sinnt starfsskyldum sínum, mynd 4 . Nefndarfundir eru að meðaltali 5,2 á ári og hver fundur hefur pví um 20\% hlutfall af heildinni. Rúmlega $40 \%$ svöruðu pví til að oftast væru fundargögn pess eðlis að hægt væri að sinna hlutverki sínu. Pví má meta pað svo að í um 85\% tilvika séu viðunandi aðstæður á nefndarfundum með tilliti til fullnægjandi fundargagna. Tæplega 10\% pátttakenda svöruðu stundum, sjaldan eða veit ekki. Slík svör mætti túlka pannig að fundargögnum sé ábótavant.

Einnig er mikilvægt að virkar umræður fari fram pegar gagnrýnar spurningar eru á 
dagskrá, pví par koma oftar en ekki fram mikilvæg atriði. Best er að alltaf séu virkar umræður, pó svo að veigalitlar spurningar eigi í hlut. Tæplega 57\% pátttakenda segja að alltaf séu virkar umræður pegar gagnrýnar spurningar eru bornar upp, mynd 5. Tæplega 95\% pátttakenda svara að virkar umræður séu alltaf eða oftast pegar gagnrýnar spurningar eru ræddar. Um $5 \%$ pátttakenda svara stundum eða veit ekki.

Tilgangurinn með pví að krosskeyra gögn er að fá vísbendingu um pað hvort fjöldi nefndarfunda hafi tengsl er snerta gæði fundargagna og umræðu að mati nefndarmanna. Spurning nr. 1 er notuð varðandi tilgátu 1 og hún krosskeyrð við prjár spurningar, nr. 3, 4 og 5. Með pessari nálgun er verið að athuga hvort hægt er að fá vísbendingu um pað hver lágmarksfjöldi nefndarfunda parf að vera til pess að gæta að gæðum fundargagna og umræðna. Spurning nr. 2 er notuð varðandi tilgátu 2 og er hún krosskeyrð við prjár spurningar, nr. 3, 4 og 5. Með pessari nálgun er er verið að athuga hvort hægt er að fá vísbendingu um pað hver lágmarksfjöldi funda með endurskoðanda parf að vera til pess að gæta að gæðum fundargagna og umræðna. Til að hafna eða ekki hafna tilgátum pá er notast við kí kvaðratpróf. Notuð er 2 × 2 nálgun. Fjöldi nefndarfunda er flokkaður í tvo hópa; 1) prjá eða færri fundi og 2) fjóra eða fleiri fundi. Fjöldi funda með ytri endurskoðanda er flokkaður í tvo hópa; 1) tvo eða færri fundi og 2) prjá eða fleiri fundi.

Tilgátu 1, gæði fundargagna endurskoðunarnefnda eru ekki tengd við fjölda nefndarfunda. Mat pátttakenda átti pað sameiginlegt að með auknum fjölda nefndarfunda hefðu gæði fundargagna og umræðu aukist, sjá töflur nr. 1, 2 og 3. Sérstaklega er bent á að pegar fjöldi nefndarfunda var fjórir eða fimm pá voru engin svör nefndarmanna pess eðlis að pau væru flokkuð ekki viðunandi. Par sem nefndarfundir voru sex eða fleiri voru svör mun færri nefndarmanna pess eðlis að pau væru flokkuð sem ekki viðunandi miðað við tvo eða prjá fundi. Раð kemur fram í mati nefndarmanna að раð er munur á gæðum fundargagna og umræðu á nefndarfundum eftir pví hversu margir nefndarfundir eru haldnir. Par sem nefndarfundir voru fjórir eða fimm voru öll svör nefndarmanna pess eðlis að pau voru flokkuð sem viðunandi. Af pessu er hægt að álykta að gæði fundargagna aukast pegar haldnir eru fjórir eða fleiri nefndarfundur í endurskoðunarnefndum. Sterk vísbending er um að tengsl séu á milli fjölda nefndarfunda og gæða fundargagna. Prír og færri nefndarfundir minnka gæði fundargagna að mati nefndarmanna. Í kí kvaðratprófinu kemur fram að marktækur munur er á milli fjölda nefndarfunda, sjá töflu nr. 1a. Tilgátu 1 er pví hafnað með tilliti til fjölda nefndarfunda og pess að fundargögn komi með nægjalegum fyrirvara til pess að nefndarmenn geti sett sig inn í málefni næsta fundar (spurning nr. 3). Niðurstaða úr kí kvaðratprófinu hvað varðar spurningar nr. 4 og 5 voru pess eðlis að ekki var hægt að hafna tilgátunni. Ekki fannst marktækur munur á milli fjölda nefndarfunda og pess að pau fundargögn sem nefndarmaður fær fyrir hvern fund séu fullnægjandi svo pú getir sinnt hlutverki pínu sem nefndarmaður (spurning nr. 4) sem og hvort virkar umræður á fundum par sem bornar eru upp gagnrýnar spurningar (spurning nr. 5).

Tilgátu 2, Gæði fundargagna endurskoðunarnefnda eru ekki tengd við fjölda nefndarfunda með ytri endurskoðendum. Mat pátttakenda átti pað sameiginlegt að ekki var hægt að greina neina breytingu með auknum fjölda funda með ytri endurskoðanda sem tengst gætu gæðum fundargagna og umræðu, sjá töflur nr. 4, 5 og 6, í pví samhengi sem hefur verið skoðað hér. Engar vísbendingar eru um að fjöldi funda endurskoðunarnefnda með ytri endurskoðanda hafi áhrif á gæði fundargagna. Í krosskeyrslu á spurningum nr. 2 og 3, tafla 4, kemur fram að í öllum fundarflokkum, fjöldi funda, er að finna svör nefndarmanna pess eðlis að pau voru flokkuð sem ekki viðunandi, frá 5,0\% til 25,0\%. Í krosskeyrslu á spurningum nr. 2 og 4, tafla 5, kemur fram að í premur af fjórum fundarflokkum er að finna svör nefndarmanna pess eðlis að pau voru flokkuð sem ekki viðunandi. Í töflu 6 kemur fram að par sem fundað var prisvar eða oftar með ytri endurskoðanda voru öll svör nefndarmanna pess eðlis að pau voru flokkuð sem viðunandi, krosskeyrsla á spurningum nr. 2 og 5, nema hjá peim sem ekki voru í endurskoðunarnefnd síðastliðið rekstrarár.

Í kí kvaðratprófinu kemur fram að ekki er til staðar marktækur munur á milli fjölda 
funda endurskoðunarnefnda með ytri endurskoðanda og breytanna priggja sem eru í spurningum nr. 3, 4 og 5. Tilgátu 2 er pví ekki hafnað með tilliti til fjölda funda endurskoðunarnefnda með ytri endurskoðanda í öllum tilvikum. Engin marktæk tengsl á milli fjölda funda með ytri endurskoðanda og peirra breytna sem er að finna í spurningum nr. 3,4 og 5 .

\section{Umræður}

Niðurstöður rannsóknarinnar benda til pess að fjöldi nefndarfunda hafi tengsl við gæði fundargagna hvað varðar tímasetningu peirra, tilgáta 1. Ekki fundust tengsl varðandi gagnrýnar umræður eða fullnægjandi fundargögn, tilgátur 1 og 2. Verklag og ábyrgð eykst að öllum líkindum pegar nefndarfundum fjölgar og festa kemst á framkvæmd funda. Ferli er einn pátta í módeli DeZoort o.fl. (2002) sem sett var fram til pess að skilgreina virkni endurskoðunarnefnda. Með pví að skoða ferlið sérstaklega, án pess að skoða pað í samhengi við inntak módelsins, er opnað á umræðu um hvað endurskoðunarnefndir gera í raun og veru (Brennan o.fl., 2015), en pað hlýtur að vera lykilpáttur í pví hvort endurskoðunarnefndir geti verið skilvirkar. Hvað varðar fjölda funda endurskoðunarnefnda með ytri endurskoðanda er ekki hægt að draga pá ályktun að fjöldi funda hafi tengsl við gæði fundargagna par sem tilgátu 2 er ekki hafnað.

Hlutverk endurskoðunarnefnda er mikilvægt til að tryggja gæði og trúverðugleika ársreikninga gagnvart öllum haghöfum. Utanaðkomandi nefndarmenn eru líklegri til að auka á trúverðugleika bæði vegna pekkingar sinnar og sjálfstæðis. Í pessu sambandi eru samhverfar (e. asymmetric) upplýsingar nauðsynlegar sem nefndarmönnum eru veittar frá fyrirtækjunum, fundargögn, og með aukinni lagalegri ábyrgð stjórnenda aukast líkur á að pær séu veittar. Undir petta taka Al-Mamun o.fl (2014) og halda pví fram að reglulegir fundir endurskoðunarnefnda ásamt upplýsingagjöf geti dregið úr umboðsvanda. Fjöldi funda er líka talinn hafa hér áhrif og rannsóknir Menon og Williams (2005) benda til pess að fjöldi funda ásamt sjálfstæði nefnda veiti meira aðhald og leiði til betri afkomu og minni umboðsvanda.

Rannsóknin er sú fyrsta sem gerð er með hliðsjón af ferli og störfum endurskoðunarnefnda á Íslandi. Rannsóknin er jafnframt sú fyrsta sem skoðar bæði fjölda funda endurskoðunarnefnda og fjölda funda endurskoðunarnefnda með ytri endurskoðenda sem vísbendingu um skilvirkni endurskoðunarnefnda. Jafnframt er leitast við að fá mynd af starfsemi endurskoðunarnefnda með pví að spyrja spurninga um gæði fundargagna og hvenær pau berast og um gagnrýna umræðu. Höfundum er ekki kunnugt um að aðrir fræðimenn hafi reynt að bera saman fjölda funda annars vegar og starfsemi endurskoðunarnefnda út frá fundargögnum og umræðum á fundum hins vegar. Hér er verið að svara kalli peirra fræðimanna sem hafa rannsakað endurskoðunarnefndir hvað mest (DeZoort o.fl., 2002; Bédard og Gendron, 2010; Fiolleau o.fl., 2019). Раð skiptir jafnframt máli að verið er að kanna endurskoðunarnefndir í íslensku samhengi, par sem pær hafa fengið litla sem enga athygli í rannsóknum en eru eins og annars staðar mikilvægur páttur í stjórnarháttum fyrirtækja.

Frekari rannsókna er pörf til pess að meta markvirkni og skilvirkni endurskoðunarnefnda. Skoða parf alla pætti DeZoort (2002) líkansins og útfærslu Bédard og Gendron (2010) betur í hlutum og sem heild. Mikilvægt er að í framhaldinu verði gerðar rannsóknir byggðar á eigindlegri aðferðafræði par sem viðtöl við nefndarmenn endurskoðunarnefnda og tengda aðila eru notuð til pess að fá dýpri innsýn í störf endurskoðunarnefnda á Íslandi.

\section{Heimildir:}

Al-Mamun, A., Yasser, Q. R., Rahman, M. A., Wickramasinghe, A., \& Nathan, T. M.(2014). Relationship between Audit Committee Characteristics, External Auditors and Economic Value Added (EVA) of Public Listed Firms in Malaysia. Corporate Ownership and Control, 12(1), 899-910. 
Anderson, R.C., Mansi, S.A., and Reeb, D.M. (2004). Board Characteristics, Accounting Report Integrity, and the Cost of Debt. Journal of Accounting and Economics, 37(3), 315- 342.

Appuhami, R. og Tashakor, S. (2017). The Impact of Audit Committee Characteristics on CSR Disclosure: An Analysis of Australian Firms. Australian Accounting Review, 27(4), 400-420. doi: 10.1111/auar.12170

ASIC, Australian Securities \& Investment Commission. (2019, September 19.). Audit Quality - The Role of Directors and Audit Committees. https://asic.gov.au/regulatory-resources/financial-reporting-and-audit/ auditors/audit-quality-the-role-of-directors-and-audit-committees/

Beasley, M., Carcello, J., Hermanson, D., \& Lapides, P. (2000). Fraudulent Financial Reporting: Consideration of Industry Traits and Corporate Governance Mechanisms. Accounting Horizons, 14, 441-454.

Bedard, J., Chtourou, S.M., and Courteau, L. (2004). The Effect of Audit Committee Expertise, Independence, and Activity on Aggressive Earnings Management. Auditing: A Journal of Theory and Practice 23(2), 13-35.

Bédard, J. and Gendron, Y. (2010). Strengthening the Financial Reporting System: Can Audit Committees Deliver? International Journal of Auditing, 14(2), 174-210.

Blue Ribbon Committee on Improving the Effectiveness of Corporate Audit Committees (1999). Report and Recommendations of the Blue Ribbon Committee on Improving the Effectiveness of Corporate Audit Committees. New York, NY: New York Stock Exchange and National Association of Securities Dealers.

Braswell, M. (2018). Audit Committee Member Tenure and Earnings Management. International Review of Accounting, Banking and Finance, 10(1/2), 43-71

Brennan, M.N. og Kirwan, D.C. (2015). Audit Committees: Practices, Practitioners and Praxis of Governance. Accounting, Auditing \& Accountability Journal, 28(4), 466-493. doi10.1108/AAAJ-01-2015-1925

Church, K.B., Jenkins, J.G. \& Stanley, D.J. (2018). Auditor Independence in the United States: Cornerstone of the Profession or Thorn in Our Side? Accounting Horizons, AAA. 32(3), 145-168. doi10.2308/acch-52122

Churchill, G. A. (2002). Marketing Research: Methodological foundations. Fort Worth: Harcourt College Publishers.

Cohen, J., Krishnamoorthy, G. \& Wright, A. (2004). The Corporate Governance Mosaic and Financial Reporting Quality. Journal of Accounting Literature, 23, 87-152.

CPA (2017, September 16.). Chartered Proffessional Accountants, Ontario. The Importance of Professional Judgment and Professional Skepticism in Conducting a Review Engagement. https://media.cpaontario.ca/stewardship-of-the-profession/pdfs/Importance-of-Professional-Judgement-and-Professional-Skepticism.pdf

Deloitte (2019, September 17.). What Audit Committees Want from CFOs. https:/www2.deloitte.com/us/en/ pages/finance/articles/cfo-insights-audit-committees.html

DeZoort, F. T., Hermanson, D., Archambeault, D. \& Reed, S. (2002). Audit Committee Effectiveness: A Synthesis of the Empirical Audit Committee Literature. Journal of Accounting Literature, 21, 38-75.

EFRAG, 2012. Towards a Disclosure Framework for the Notes. Discussion paper. European Financial Reporting Advisory Group, Belgium.

Einar Guðbjartsson og Jón Snorri Snorrason (2017). Umhverfi og starfsemi endurskoðunarnefnda - bakgrunnur nefndarmanna og traust á fjárhagsupplýsingum. Tímarit um viðskipti og efnahagsmál, 14(1), 25-42.

Einar Guðbjartsson, Eypór I. Jónsson og Jón Snorri Snorrason (2018). Endurskoðunarnefndir: Samsetning og góðir stjórnarhættir. Tímarit um viðskipti og efnahagsmál, 15(2), 73-96.

EU, 537/2014 (2019, September 17.). EU-Regulation No. 537/2014 of the European Parliament and the Council of 16 April 2014, on specific requirements regarding statutory audit of public-interest entities and repealing Commission Decision 2005/909/EC. https://eur-lex.europa.eu/legal-content/EN/TXT/?uri=CELEX\%3A32014R0537

EU (2006). (2017, August 17.). Directive 2006/43/EC of the European Parliament and of the Council. https:// eur-lex.europa.eu/legal-content/EN/TXT/?uri= CELEX\%3A02006L0043-20140616

Fama, E.F. \& Jensen, M. (1983). Separation of Ownership and Control. Journal of Law and Economics, 26, 301-325.

FEE, 2016. (2017, September 15). Federation of European Accountants, 1040 Brüssel, January 2016. https:// www.accountancyeurope.eu/publications/the-impact-of-the-audit- reform-on-audit-committees-in-europe/

Fiolleau, K., Hoang, K. \& Pomeroy, B. (2019). Auditors' Communication with Audit Committees: The Influence of the Audit Committee's Oversight Approach. Auditing: A Journal of Practice $\mathcal{E}$ Theory, 28(2), 125 - 150.

FRC (2012). (2019, September 16.). Financial Reporting Council. Guidance on Audit Committees. https://www. frc.org.uk/getattachment/9ac07916-ea56-4027-864a-11ef9bfa24e4/Guidance-on-Audit-Committees-(September-2012).pdf

IFRS (2017). Disclosure Initiative-Principles of Disclosure. Discussion Paper DP/2017/1. IFRS Foundation Publications Department. London. UK.

IFRS 7. Financial Instruments: Disclosure. IASB 2009.

IFRS 12. Disclosure of Interests in Other Entities. IASB 2013.

IFRS 13. Fair Value Measurement. IASB 2013.

IFRS 16. Leases. IASB 2019.

Jenkins, J. G. \& Stanley, D. J. (2019). A Current Evaluation of Independence as a Foundational Element of the Auditing Profession in the United States. Current Issues in Auditing, 13(1), 17-27. 
Jensen, M.C. \& Meckling, W.H. (1976). Theory of the Firm, Managerial Behaviour, Agency Costs and Ownership Structure, Journal of Financial Economics, 3(4), 305-60.

Kolk, A. \& Pinkse, J. (2010). The Integration of Corporate Governance in Corporate Social Responsibility Disclosures, Corporate Social Responsibility and Environmental Management, 17(1), 15-26.

Li, X., \& Yang, H.I. 2015, 'Mandatory Financial Reporting and Voluntary Disclosure: The Effect of Mandatory IFRS Adoptionon Management Forecasts', The Accounting Review, 91(3): 933-53.

Lög um ársreikninga, nr. 3 frá 2006.

Lög um endurskoðendur og endurskoðun, nr. 94 frá 2019.

Mangena, M., \& Tauringana, V. (2008). Audit Committees and Voluntary External Auditor Involvement in UK Interim Reporting. International Journal of Auditing, 12(1), 45-63.

McMullen, D.A., \& Raghundandan, K. 1996. Enhancing Audit Committee Effectiveness. Journal of Accountancy, 182(2), 79-82.

McDaniel, L., Martin, R. D., \& Maines, L. A. (2002). Evaluating Financial Reporting Quality: The Effects of Financial Expertise vs. Financial Literacy. The Accounting Review, 77(4 Supplement: Quality of Earnings Conference), 139-167.

Menon, K., \& Williams, J. D. (1994). The Use of Audit Committees for Monitoring. Journal of Accounting and Public Policy, 13(2), 121-139.

NACD, National Association of Corporate Directors (2000). Report of the NACD Blue Ribbon Commission on Audit Committees: A practical guide. Washington, DC: National Association of Corporate Directors.

NYSE: Corporate Governance Guide. First published: 2014. (2019, September 18.). ISBN: 978-0-9565842-6-7

Power, M.K. \& Gendron, Y. (2015). Research Forum on Qualitative Research in Auditing. Auditing: A Journal of Practice E Theory. 34(2), 1-2. DOI: 10.2308/ajpt-10458

Ragnheiður Harpa Arnardóttir (2013). Megindlegar rannsóknir: Gerð rannsóknaráætlunar og yfirlit yfir helstu rannsóknarsnið. Sigríður Halldórsdóttir (ritstjóri), Handbók i aðferðafræði rannsókna (377-392). Akureyri: Háskólinn á Akureyri.

Sabia, M. J. \& Goodfellow, J. L. (2005). Integrity in the Spotlight, 2nd ed. Toronto: The Canadian Institute of Chartered Acountants.

Spira, L. F. (2002). The Audit Committee: Performing Corporate Governance. Boston, MA: Kluwer.

Verriest, A., Gaeremynck, A. \& Thornton, D.B. (2013). The Impact of Corporate Governance on IFRS Adoption Choices. European Accounting review, 22(1): 39-77.

Williams, S. P. (2005). Meet the Experts. Accounting Horizons, 19(4), 255-265.

Wu, J., Habib, A., Weil, S. \& Wild, S. (2017) Exploring the Identity of Audit Committee Members of New Zealand Listed Companies. International Journal of Auditing, 22(2), 164-184. DOI: 10.1111/ijau.12111. 